\title{
Development of a climate record of tropospheric and stratospheric column ozone from satellite remote sensing: evidence of an early recovery of global stratospheric ozone
}

\author{
J. R. Ziemke ${ }^{1,2}$ and S. Chandra ${ }^{3}$ \\ ${ }^{1}$ Goddard Earth and Sciences Technology and Research, Morgan State University, Baltimore, Maryland, USA \\ ${ }^{2}$ NASA Goddard Space Flight Center, Greenbelt, Maryland, USA \\ ${ }^{3}$ Goddard Earth Sciences and Technology, University of Maryland Baltimore County, Baltimore, Maryland, USA \\ Correspondence to: J. R. Ziemke (jerald.r.ziemke@nasa.gov)
}

Received: 17 October 2011 - Published in Atmos. Chem. Phys. Discuss.: 30 January 2012

Revised: 6 April 2012 - Accepted: 12 June 2012 - Published: 3 July 2012

\begin{abstract}
Ozone data beginning October 2004 from the Aura Ozone Monitoring Instrument (OMI) and Aura Microwave Limb Sounder (MLS) are used to evaluate the accuracy of the Cloud Slicing technique in effort to develop long data records of tropospheric and stratospheric ozone and for studying their long-term changes. Using this technique, we have produced a 32-yr (1979-2010) long record of tropospheric and stratospheric column ozone from the combined Total Ozone Mapping Spectrometer (TOMS) and OMI. Analyses of these time series suggest that the quasi-biennial oscillation $(\mathrm{QBO})$ is the dominant source of inter-annual variability of stratospheric ozone and is clearest in the Southern Hemisphere during the Aura time record with related inter-annual changes of 30 40 Dobson Units. Tropospheric ozone for the long record also indicates a QBO signal in the tropics with peak-to-peak changes varying from 2 to $7 \mathrm{DU}$. The most important result from our study is that global stratospheric ozone indicates signature of a recovery occurring with ozone abundance now approaching the levels of year 1980 and earlier. The negative trends in stratospheric ozone in both hemispheres during the first $15 \mathrm{yr}$ of the record are now positive over the last $15 \mathrm{yr}$ and with nearly equal magnitudes. This turnaround in stratospheric ozone loss is occurring about $20 \mathrm{yr}$ earlier than predicted by many chemistry climate models. This suggests that the Montreal Protocol which was first signed in 1987 as an international agreement to reduce ozone destroying substances is working well and perhaps better than anticipated.
\end{abstract}

\section{Introduction}

The measurement of tropospheric ozone from satellite remote sensing began with the studies by Fishman and Larsen (1987) and Fishman et al. (1990). In those studies tropospheric column ozone (TCO) was derived by subtracting co-located stratospheric column ozone (SCO) from total column ozone. SCO was calculated from Stratospheric Aerosol and Gas Experiment (SAGE) ozone profile measurements while Total Ozone Mapping Spectrometer (TOMS) measurements were used for total column ozone. The method was named the tropospheric ozone residual (TOR) technique and was effective in producing global maps of tropospheric ozone albeit limited primarily to a seasonal climatology due to sparse data sampling for SAGE because of its occultation technique. Chandra et al. (2003) used the greater spatial and temporal coverage of stratospheric ozone from the Upper Atmosphere Research Satellite (UARS) Microwave Limb Sounder (MLS) in combination with TOMS total ozone to improve monthly maps of TOR. More recently Ziemke et al. (2006) and Schoeberl et al. (2007) used two separate residual algorithms combining Aura Ozone Monitoring Instrument (OMI) and Aura MLS measurements to produce global fields of TOR with improved temporal and spatial coverage beyond previous studies.

An alternative residual technique is the convective-cloud differential (CCD) method (Ziemke et al., 1998) which uses total column ozone and SCO from the same satellite instrument. The CCD method is the most basic form of "cloud slicing" for measuring tropospheric and stratospheric ozone 
(e.g., Ziemke et al., 2001, 2009, and references therein). Gridded measurements from the CCD method are restricted to the tropics; however mid-to-high latitude measurements may be obtained with this method and are given generally as zonal averages over the Pacific. An advantage with the CCD method is that by using a single instrument the potential errors arising from residual differencing are largely alleviated. This is important for deriving a long record of TCO and SCO from several combined instruments.

The CCD technique takes advantage of the fact that UVmeasuring instruments such as Total Ozone Mapping Spectrometer (TOMS), Global Ozone Monitoring Experiment (GOME), and OMI do not measure ozone lying below optically thick clouds. The CCD method assumes that one can make an accurate estimate of SCO using highly reflecting deep convective clouds (reflectivity $R>0.8$ ) in the tropical Pacific region. It was shown by Ziemke et al. (2009) from combined Aura OMI and MLS measurements that ozone concentrations inside thick clouds in the Pacific are small to within a few ppbv. The CCD method works well for deriving SCO in the Pacific because the above-cloud column ozone measured by OMI for thick clouds is essentially equivalent to SCO to within 1-2 DU. The CCD method of Ziemke et al. (1998) further assumes that SCO is invariant along longitude in the tropics. With these assumptions, TCO in tropical latitudes can be calculated at any given location by differencing low reflectivity $(R<0.2)$ total column ozone and high reflectivity $(R>0.8)$ SCO from the Pacific region within the same latitude range. Highly reflecting clouds generally do not have physical cloud heights reaching tropopause altitude and the column ozone above the cloud may vary considerably even when $R>0.8$. As a practical solution, $\mathrm{SCO}$ in the Pacific is calculated using only minimum values of abovecloud column ozone in each gridded region. These minimum values are then averaged over the eastern and western tropical Pacific to derive a single measurement of SCO.

The validity of these assumptions has been established by comparing TCO and SCO derived from the CCD method with TCO and SCO derived from ozonesondes and satellite data including TOMS/MLS, TOMS/Halogen Occultation Experiment instrument (HALOE), and TOMS/SAGE combinations (e.g., Ziemke et al., 1998, 2005; Chandra et al., 2003). Application of the CCD method from TOMS data was extended over the Pacific region into the middle and high latitudes between $50^{\circ} \mathrm{S}$ and $60^{\circ} \mathrm{N}$ (Ziemke et al., 2005) for the time record 1979-2003.

The objective of this study is to evaluate strengths and weaknesses of the CCD technique by incorporating Aura OMI and MLS ozone and to study inter-annual and decadal changes in tropospheric and stratospheric ozone. The Aura MLS measurements of SCO provide a stringent test of CCD SCO when compared to sparse satellite occultation measurements in previous studies. This is important for establishing a long record (1979-present) of CCD TCO and SCO from combined OMI and TOMS instrument measurements. Long record data products are important for addressing issues including trends in tropospheric ozone and pollution, stratospheric ozone depletion, and decadal changes in the global Brewer Dobson Circulation.

In the following, Sect. 2 discusses the Aura OMI and MLS measurements, Sect. 3 describes the CCD and OMI/MLS residual methodologies, Sect. 4 discusses inter-annual variability of tropospheric and stratospheric ozone, Sect. 5 discusses some results from the TOMS+OMI 1979-2010 extended ozone dataset, and finally Sect. 6 provides a summary.

\section{Aura OMI and MLS ozone measurements}

The OMI and MLS are two out of a total of four instruments onboard the Aura spacecraft which is flown in a sunsynchronous polar orbit at $705 \mathrm{~km}$ altitude with a $98.2^{\circ}$ inclination. Aura was launched in July 2004 and has been providing measurements since August 2004 to the present. The spacecraft has an equatorial crossing time of 01:45 p.m. (ascending node) with around 98.8 min per orbit (14.6 orbits per day on average). Schoeberl et al. (2006) provide an overview of the EOS Aura mission and discuss the various measurements from the four Aura instruments.

The OMI is a nadir-scanner which at visible $(350-500 \mathrm{~nm})$ and UV wavelength channels (UV-1: 270-314 nm; UV-2: 306-380 nm) detects backscattered solar radiance to measure column ozone with near global coverage (aside from polar night latitudes) over the Earth with a resolution of $13 \times 24 \mathrm{~km}$ at absolute nadir. Aside from ozone, OMI also measures Optical Centroid Cloud Pressure (OCCP), aerosols, $\mathrm{NO}_{2}, \mathrm{SO}_{2}, \mathrm{HCHO}$, and several other trace gases in the troposphere and stratosphere (Levelt et al., 2006). Measurements of ozone from OMI are determined using the OMTO3 v8.5 algorithm which is an extension of the TOMS $\mathrm{v} 8$ algorithm. A description of the TOMS v8 algorithm may be obtained from the TOMS V8 CD DVD ROM, or from the OMI Algorithm Theoretical Basis Document (ATBD) from the TOMS web page (http://toms.gsfc.nasa.gov/version8/ v8toms_atbd.pdf). One difference between the TOMS v8 and the OMTO3 v8.5 algorithms is the treatment of clouds. The TOMS v8 and earlier versions of OMTO3 use a cloud pressure climatology based on thermal infrared cloud-top pressures, whereas OMTO3 v8.5 uses in situ OCCP derived with OMI by the rotational Raman scattering method.

SCO is calculated for the OMI/MLS residual method using MLS v2.2 ozone. The MLS instrument is a thermal-emission microwave limb sounder that measures vertical profiles of mesospheric, stratospheric, and upper tropospheric temperature, ozone, and several other constituents from limb scans taken in the direction ahead of the Aura satellite orbital track. The MLS profile measurements are made about $7 \mathrm{~min}$ before OMI views the same location during ascending (daytime) orbital tracks. These we refer to as "co-located" measurements between OMI and MLS. MLS also measures ozone 


\section{Tropospheric Ozone Measured by OMI/MLS and OMI CCD}

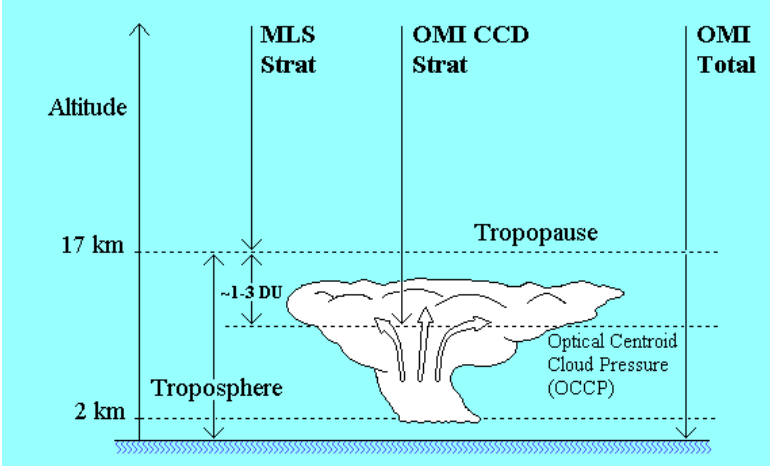

(CCD: "Convective Cloud Differential - i.e., most basic form of "Cloud Slicing")

Fig. 1. Schematic illustration of the OMI/MLS tropospheric ozone residual method of Ziemke et al. (2006) (OMI total column ozone minus MLS stratospheric column ozone) and the convective-cloud differential (CCD) residual method of Ziemke et al. (1998) (OMI total column ozone minus OMI above-cloud column ozone).

and other atmospheric constituents for descending nighttime orbits which on a given day can be up to $\pm 12 \mathrm{~h}$ different in time from OMI daytime measurements. With combined ascending and descending nodes MLS makes around 3500 vertical profile measurements over the Earth per day. This study includes only the ascending orbit co-located data from MLS for deriving SCO. Details regarding the instrument including spectrometers, spectral channels, calibration, and other topics are discussed by Waters et al. (2006) and in related papers in the same journal. Froidevaux et al. (2008, and personal communication, 2011) provides validation results for MLS v2.2 measurements of ozone and other trace gases. At the present time an MLS v3.3 data product is also provided to the science community. While v2.2 retrieval has 37 pressure levels, v3.3 has 55 pressure levels and other improvements; however, v3.3 also has more outliers/missing data in the ozone measurements than with v2.2. Our analysis of SCO derived from MLS shows that there is little difference between using v2.2 or v3.3 other than a small systematic offset (v3.3 minus v2.2) of about 2.5 DU. Information regarding MLS v3.3 ozone measurements is available online from the NASA Data and Information Services Center (http://disc.sci. gsfc.nasa.gov/gesNews/mls_new_data_version_release).

\section{Retrieval methodologies and comparison of results}

Two residual methods are used for deriving TCO and SCO from Aura OMI and MLS measurements. One is the OMI/MLS approach of Ziemke et al. (2006) and the other is the CCD method of Ziemke et al. (1998). Figure 1 is a schematic diagram illustrating both of these residual tech- niques in the tropics where the tropopause is typically $\sim 16-$ $17 \mathrm{~km}$ altitude year-round.

\subsection{The OMI/MLS residual method}

For the OMI/MLS residual method in Fig. 1, SCO is derived from vertically integrated MLS ozone profiles which are subtracted from OMI near clear-sky (radiative cloud fractions $<30 \%$ ) total column ozone to derive TCO. Tropopause pressure, which separates tropospheric from stratospheric column ozone comes from National Centers for Environmental Prediction (NCEP) using the World Meteorological Organization (WMO) $2 \mathrm{~K} \mathrm{~km}^{-1}$ lapse rate tropopause definition. SCO from MLS is determined by pressure integration of ozone volume mixing ratio profiles from $0.0215 \mathrm{hPa}$ down to the NCEP tropopause. The MLS ozone profile measurements were linearly interpolated in log-pressure to the existing NCEP tropopause pressure to derive SCO. MLS SCO (in

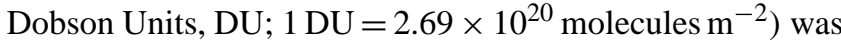
determined by standard log-pressure integration of ozone volume mixing ratio: $\mathrm{SCO}=0.79 \int_{0.0215 \mathrm{hPa}}^{\mathrm{Ptropopause}} X P \cdot \mathrm{d} \ln P$, where $X$ is ozone volume mixing ratio in units ppbv and $P$ is pressure in units $\mathrm{hPa}$. The recommended range for scientific analysis of MLS v2.2 ozone profiles is $0.0215-215 \mathrm{hPa}$. As was done by Ziemke et al. (2006), nearly global SCO from MLS for each day was achieved by including ozone retrievals down to $316 \mathrm{hPa}$.

MLS SCO data were binned to $1^{\circ}$ latitude $\times 1.25^{\circ}$ longitude to be compatible with OMI level-3 (L3) gridded total column ozone. Tropopause pressures from NCEP analyses were re-binned to this same resolution from a coarser $2.5 \times 2.5^{\circ}$ gridding. It is noted for MLS limb measurements that the horizontal optical path is about $300 \mathrm{~km}$ which is larger than the horizontal size of OMI L3 gridded data, but is comparable to the size of original NCEP gridded measurements. To derive a high density SCO field we have used the two-step spatial interpolation of Ziemke et al. (2006). The interpolation for SCO includes first a moving 2-D (latitude/longitude) Gaussian window along daytime orbit to fill in intermittent gaps along-track for MLS SCO, followed secondly by a linear interpolation along longitude between existing MLS SCO data. This interpolation approach preserves the along-track measurements of SCO from MLS at all latitudes. NCEP measurements of tropopause pressure were rebinned to the same $1^{\circ}$ latitude $\times 1.25^{\circ}$ longitude resolution. Following the determination of SCO and TCO at $1 \times 1.25^{\circ}$ resolution, the SCO data were averaged in $5 \times 5^{\circ}$ bins to be compatible with OMI SCO from the CCD method.

\subsection{The CCD residual method}

The CCD method illustrated in Fig. 1 uses a collective ensemble of high reflectivity (i.e., reflectivity $R>0.8$ ) abovecloud column ozone measurements from OMI within specified gridded regions (here $5^{\circ}$ latitude $\times 5^{\circ}$ longitude boxes) 
to determine SCO. Cloud tops that lie lower in the troposphere will have larger above-cloud column ozone amounts provided that spatial variability of ozone is small over the region. High reflectivity scenes represent generally deep convective cloud systems, however their physical cloud tops may not generally reach tropopause altitude and column ozone above the cloud may vary considerably even with $R>0.8$. As a practical approach, SCO in the Pacific with the original CCD algorithm of Ziemke et al. (1998) is estimated statistically within each gridded region using only minimum values of above-cloud column ozone. This is done within each region by subtracting $2 \sigma$ from the mean value where $\sigma$ is calculated RMS of the ensemble. All calculations are made each day with an absolute minimum number of $R>0.8$ level-2 footprint scenes in each $5 \times 5^{\circ}$ region chosen as 10 .

The minimum ensemble values are associated with deep convective clouds with small ozone concentration lying between the OCCP and the tropopause. Evidence for the latter effect in the tropical Pacific was shown by Kley et al. (1996) during the Central Equatorial Pacific Experiment (CEPEX). Their study indicated from ozonesondes near-zero ozone concentrations in the upper troposphere with the passing of deep convective cloud systems. Possible mechanisms stated for the exceedingly low ozone measurements in the upper troposphere included chemical destruction of ozone by yet unidentified reactions and vertical transport via convective clouds of very low ozone concentrations from the low troposphere. Low ozonesonde concentration in the upper troposphere is also described in later studies by Folkins et al. (2002) and Solomon et al. (2005) as an indicator of deep convection and associated vertical injection of low ozone amounts upwards from the boundary layer/low troposphere. Vömel and Diaz (2010) in a more recent paper suggest that the near-zero ozone concentrations in the upper troposphere by Kley et al. (1996) were biased low because of uncertainties in ozonesonde cell currents. Following a reprocessing of the CEPEX ozonesondes, Vömel and Diaz (2010) indicated that lowest ozonesonde concentrations in the upper troposphere in the Pacific may be more typically $\sim 10$ ppbv. Assuming a constant mixing ratio of $10 \mathrm{ppbv}$ lying between the tropopause and OMI OCCP $(\sim 300-500 \mathrm{hPa}$ for minimum above-cloud ozone scenes) this is equivalent to $1-3 \mathrm{DU}$ in column amount. Even with such non-zero ozone concentrations lying between the tropopause and OCCP for thick clouds, the estimate of SCO in the tropical Pacific from the CCD method should still be accurate to about $1-3$ DU in absolute numbers.

\subsection{Comparison of results}

In the following, comparisons are made between tropospheric ozone derived from the two techniques followed by further discussion of the CCD method and ozone associated with deep convective clouds.

\subsubsection{Comparisons of CCD and OMI/MLS gridded tropical TCO measurements}

The primary measurement derived from the CCD method of Ziemke et al. (1998) is gridded TCO in low tropical latitudes. We have evaluated the CCD TCO data from OMI by comparing with coincident OMI/MLS residual measurements. Figure 2 shows TCO from the CCD method (left panels) with TCO from OMI/MLS (right panels) for four consecutive October months beginning in 2004. It is well known that October (like September and November) coincide each year with large enhancements of tropospheric ozone in the tropical south Atlantic. This zonal wave-one pattern in TCO in the tropics is caused largely by a combination of effects from the Walker circulation and photochemical sources which include biomass burning and lightning (e.g., Sauvage et al., 2007, and references therein).

There is inter-annual variability present in Fig. 2 in the Atlantic region where year-to-year differences are $\sim 10 \mathrm{DU}$. October 2004 and 2006 coincided with two El Nino events whereas October 2005 was non-ENSO (i.e., neither El Niño nor La Liña conditions) and October 2007 coincided with a strong La Nina event. Although ENSO events are predominantly an Indian Ocean/Pacific Ocean phenomenon, it is possible that ENSO may have contributed in some way to the inter-annual variability of ozone in the Atlantic. It is also possible that the year-to-year changes in ozone in Fig. 2 are not related to ENSO. There is evidence in Fig. 2 of reduction of tropical tropospheric ozone in years 2004 and 2006 related to the quasi-biennial oscillation (QBO) (discussed later in Sect. 5.1). The analysis of inter-annual variability of TCO in the Atlantic is beyond the scope and purpose of this study.

Figure 3 shows a scatter plot comparing the two TCO products accumulated over the entire six years in the tropical domain $15^{\circ} \mathrm{S}-15^{\circ} \mathrm{N}$ (as shown in Fig. 2). The ensemble averages and RMS values listed in Fig. 3 are comparable for the two products with average values of about $27 \mathrm{DU}$ and $6 \mathrm{DU}$, respectively. The calculated RMS of CCD minus OMI/MLS difference time series is much smaller at around $3 \mathrm{DU}$ with an overall correlation between the two datasets of 0.88 . The conclusion from Figs. 2 and 3 is that these two gridded products are essentially similar with an average of about $3 \mathrm{DU}$ statistical RMS difference and nearly zero offset.

\subsubsection{Tropospheric ozone associated with deep convective clouds}

A key uncertainty of the CCD method is the abundance of ozone lying inside deep convective clouds. Figure 4 shows seasonal contour plots of the difference of OMI CCD minimum above-cloud column ozone minus MLS SCO averaged over the six years. We refer to these residual differences in Fig. 4 as "cloud ozone" which represents tropospheric column ozone lying between the tropopause and OCCP under conditions of deep convection (i.e., scene reflectivity 

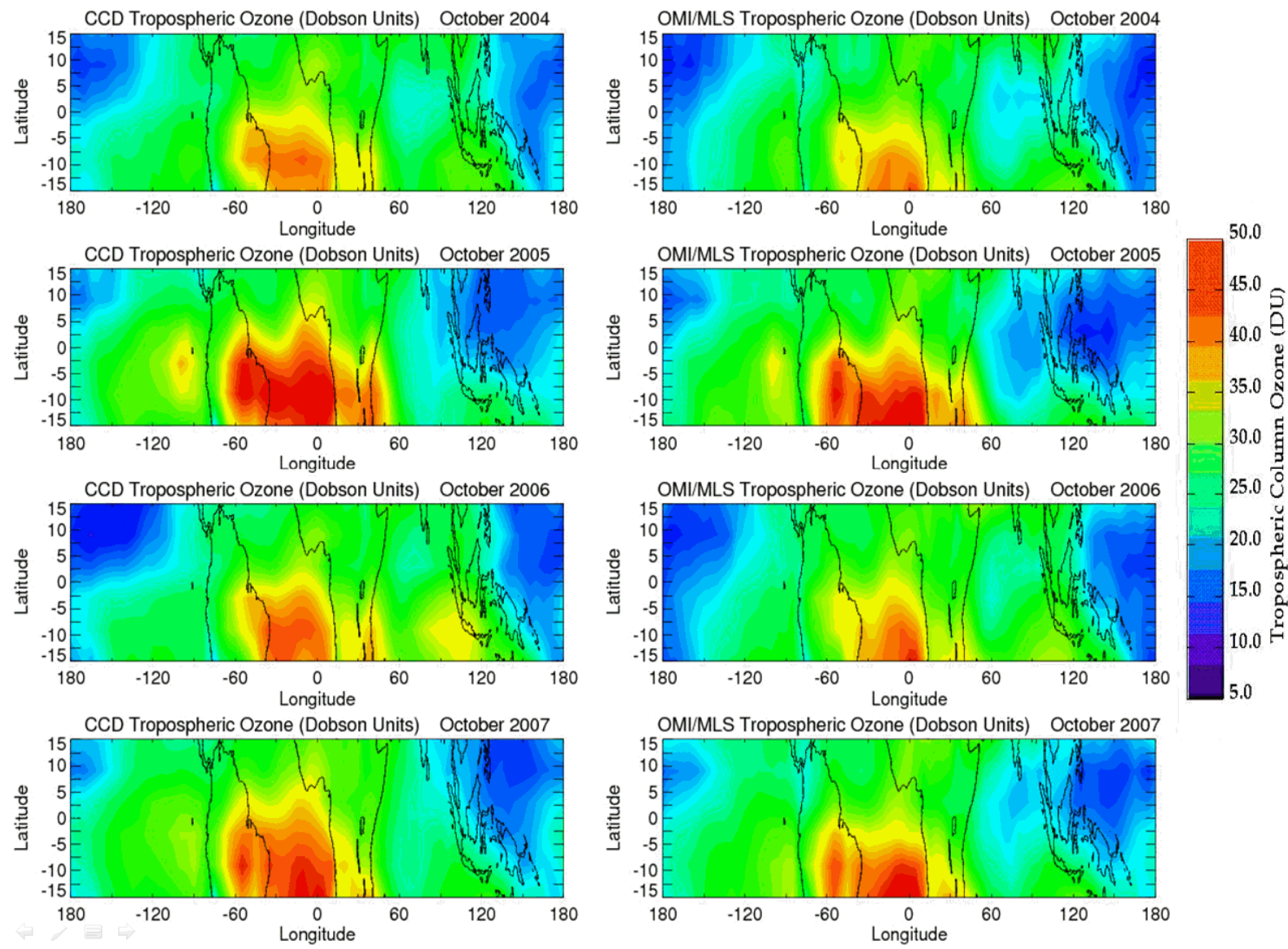

Fig. 2. Tropospheric column ozone (in Dobson Units) derived from the CCD residual method (left panels) and the OMI/MLS residual method (right panels) for four consecutive October months beginning in 2004. Blue to red colors represent smallest to largest values, respectively.

exceeding 0.8). Some measurements in Fig. 4 are negative and exceed $-5 \mathrm{DU}$ in high latitudes, particularly during winter months. The negative column amounts in Fig. 4 are obviously not correct and are caused by yet unresolved offset differences between MLS SCO and OMI above-cloud column ozone in wintertime high latitudes where solar zenith angles are highest, often exceeding $75^{\circ}$.

It is possible that column differences in Fig. 4 could in part involve ozone measurement errors over thick clouds from OMI. Liu et al. (2004) discusses ozone retrieval errors (positive offset errors) in column ozone measurements over thick clouds caused by the assumption of opaque Lambertian cloud surfaces in the TOMS algorithm. Liu et al. (2004) invoked a radiative transfer model to investigate an older version 7 TOMS ozone algorithm which used infrared cloud pressure climatology. In comparison, OMI ozone measurements in Fig. 4 use in situ OCCPs which vary with each footprint measurement and generally lie several hundred $\mathrm{hPa}$ lower in altitude than IR cloud pressures. It is difficult to assess potential OMI cloud ozone errors with the Liu et al. (2004) TOMS version 7 results. However, Ziemke et al. (2009) did show for tropical latitudes that the OMI ozone retrievals over thick clouds yielded consistent and well-calibrated ozone concentrations and column amounts.

Ideally, wherever the CCD method correctly derives local measurements of SCO the differences between the two ozone datasets in Fig. 4 should be zero. The differences in Fig. 4 are generally small in the Pacific extending from the tropics to high latitudes, but there are offset differences as large as $10 \mathrm{DU}$ or even $20 \mathrm{DU}$ in the extra-tropics of both hemispheres in regions away from the Pacific. It will be shown that these offset differences are mostly recurring annual cycle features and that tropospheric and stratospheric ozone from the CCD method are more accurate after these measurements are deseasonalized. The small differences in the Pacific sector motivate the use of the CCD technique in analyses to follow.

The column ozone differences in Fig. 4 in the tropics are consistent with the tropical cloud-ozone concentrations measured by Ziemke et al. (2009); that is, low ozone in the western-eastern Pacific year-round with high ozone over northern and southern Africa for July and October months (e.g., their Figure 9). The method used to derive cloud ozone by Ziemke et al. (2009) was different than the method used 


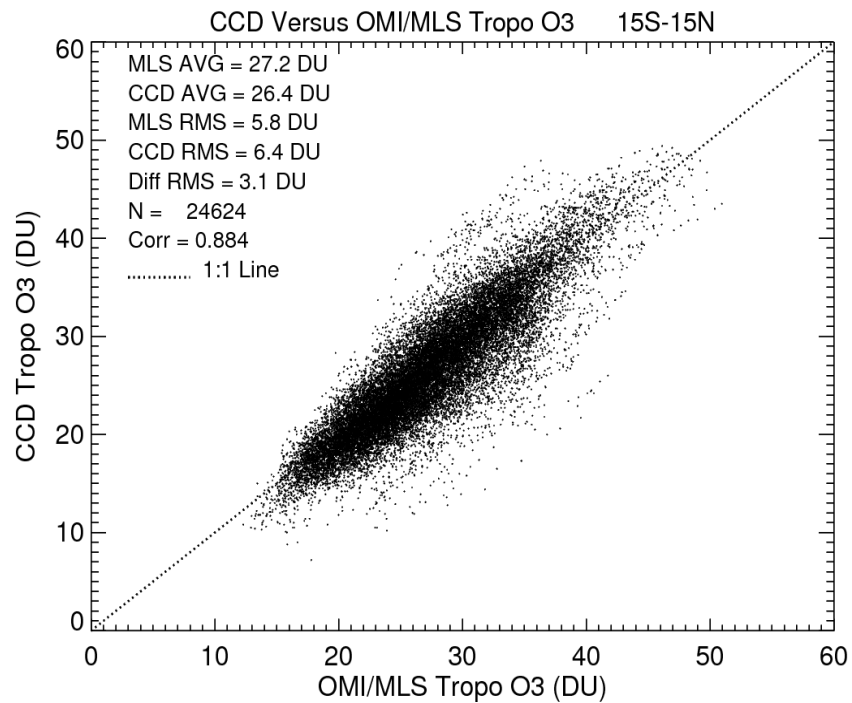

Fig. 3. Scatter plot of CCD versus OMI/MLS monthly mean gridded tropospheric column ozone (in Dobson Units) accumulated over the six-year record in the tropics. The measurements for both products are gridded at $5 \times 5^{\circ}$ latitude-longitude resolution and extend from central latitudes $12.5^{\circ} \mathrm{S}$ to $12.5^{\circ} \mathrm{N}$ along all longitudes.

in Fig. 4. Ziemke et al. (2009) determined OMI above-cloud column ozone by using OMI in situ OCCP measurements. Above-cloud column ozone in Fig. 4 is instead determined from the CCD method which does not require cloud pressures.

Ziemke et al. (2009) surmised that deep convection in the tropics could explain much of the measured low-to-high ozone concentrations associated with thick clouds. That is, low tropospheric ozone values in the Pacific and high tropospheric ozone values over Africa and South America for thick cloud scenes were hypothesized as being largely a manifestation of boundary layer ozone injected into the clouds from below. Ziemke et al. (2009) however could not distinguish between boundary layer ozone injected into the thick clouds and background ambient ozone lying above OCCP as a mixture from other sources such as stratospheretroposphere exchange (STE), lightning, and biomass burning. Despite smaller influence from STE in the tropics it was not possible to distinguish cloud-injection from other sources for the measured ozone concentrations over deep convective clouds.

In Fig. 4 it is not possible to assess the sources for the large positive cloud ozone columns for any region, especially in the extra-tropics in and near tropospheric wind jets where there is large day-to-day spatial variability and uncertainties in column ozone amounts. Furthermore, the largest CCD minus MLS column ozone differences in Fig. 4 are not necessarily a direct result of local deep convection and large boundary layer ozone concentration, but instead could be caused by substantial amount of ozone lying above OCCP from other extra-tropical sources (such as STE) under conditions of low cloud height and high reflectivity.

The OMI measurements in Fig. 4 include optically thick clouds with $R>0.8$, but even optically thick clouds in many regions are not deeply convective and have geometrical cloud tops often lying well below tropopause. This condition applies to most of the oceanic regions aside from the InterTropical Convergence Zone (ITCZ). The large positive column ozone amounts in the subtropics of both hemispheres in Fig. 4 coincide most generally with these regions were OCCP lies well below tropopause pressure for thick cloud scenes.

It is possible that the large positive ozone differences in Fig. 4 can be explained as substantial ozone amounts lying above thick cloud coming from various sources (such as STE) simply under the conditions of low cloud height and high reflectivity. One might predict that largest positive column ozone amounts in Fig. 4 will coincide with largest differences between tropopause and OCCP for thick cloud scenes, but it turns out that this is not the case. We have calculated OCCP minus tropopause pressure for $R>0.8$ scenes and find that there is no significant positive correlation between the pressure differences and the column ozone differences in Figure 4. The pressure thickness comparisons do not contribute to understanding the ozone differences in Fig. 4 for deep convective clouds and are not shown here. One would need to know the amount of surface/boundary layer ozone injected into thick clouds from below relative to other sources of ozone lying within and above the clouds. Understanding the sources and magnitude of cloud ozone in Fig. 4 would require extensive cloud/convection modeling which is beyond the scope of our study.

\section{Comparisons between ambient ozone and cloud ozone}

Line plots of 12-month annual cycles of CCD cloud ozone in the Pacific in $20^{\circ}$ latitude bands from $60^{\circ} \mathrm{S}$ to $60^{\circ} \mathrm{N}$ are shown as solid curves in Fig. 5. Also plotted as dotted curves in Fig. 5 are corresponding TCO time series from OMI/MLS. We refer to these measurements as background "ambient" tropospheric ozone. Included in Fig. 5 for all time series are calculated standard error of mean numbers which provide a measurement proportional to inter-annual variability; as example, inter-annual variability for cloud ozone in high latitudes in Fig. 5 is around 3-4 time larger than in the tropics.

The annual cycles and annual mean values for cloud ozone measurements in the tropics in Fig. 5 are small at only about 1-3 DU, however annual cycles and annual means can exceed $5 \mathrm{DU}$ in the extra-tropics. Ambient ozone in Fig. 5 maximizes in spring-summer months (March-July) in the Northern Hemisphere and the spring months (SeptemberNovember) in the Southern Hemisphere. The cloud ozone in Fig. 5 is always substantially smaller than ambient ozone at all latitude ranges, yet within the RMS uncertainties the annual cycles are generally similar for both column amounts. 

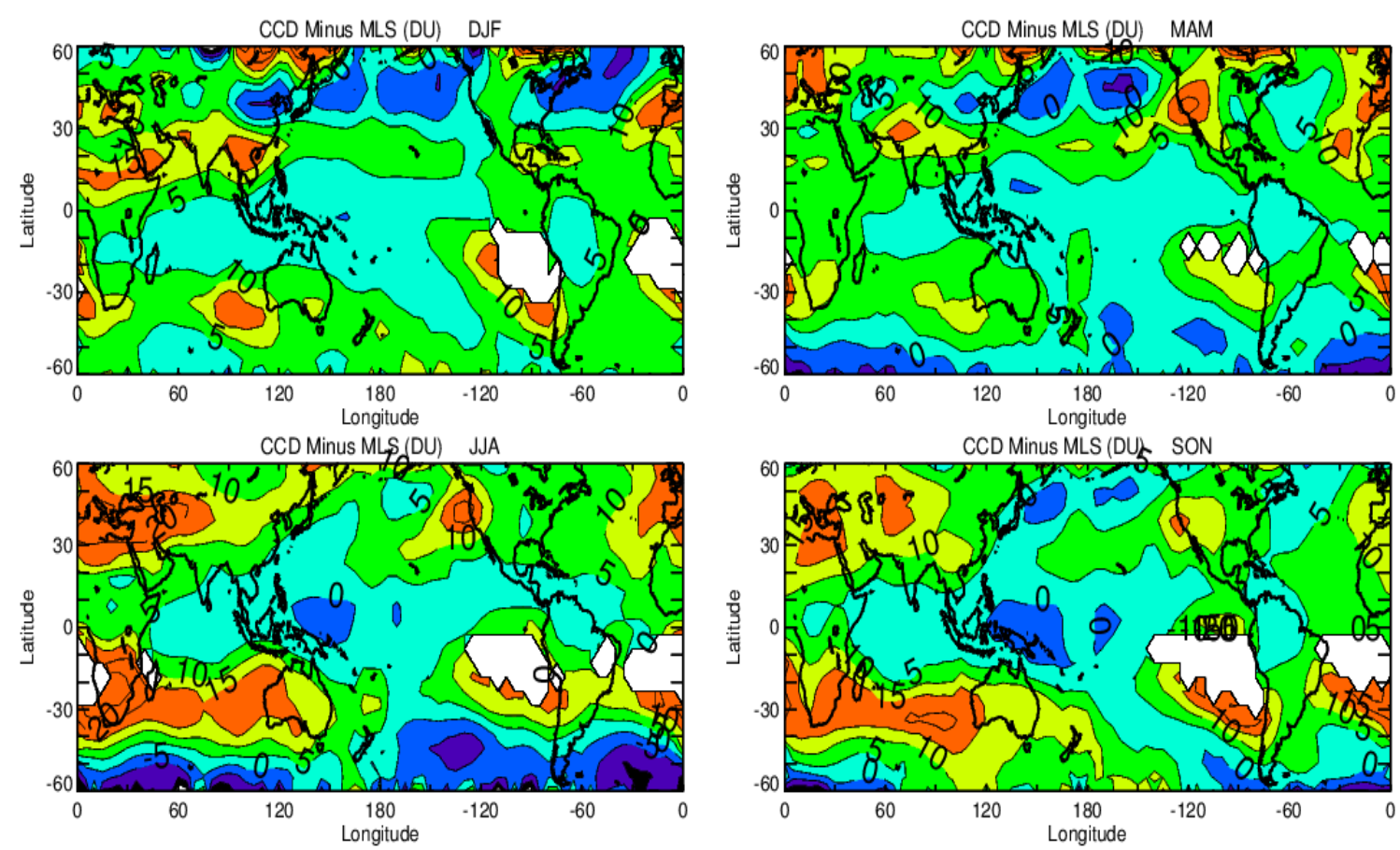

Fig. 4. Three-month seasonal averages (December-February, March-May, June-August, and September-November) of CCD above-cloud column ozone minus MLS stratospheric column ozone over the time record 2004-2010. Contour numbers represent Dobson Units. The colors violet/blue to orange represent negative to positive values, respectively. We denote these measurements in this figure as "cloud ozone", the amount of column ozone lying between the tropopause and cloud OCCP under conditions of deep convection. White regions denote areas where there is insufficient number of deep convective clouds for the CCD method.
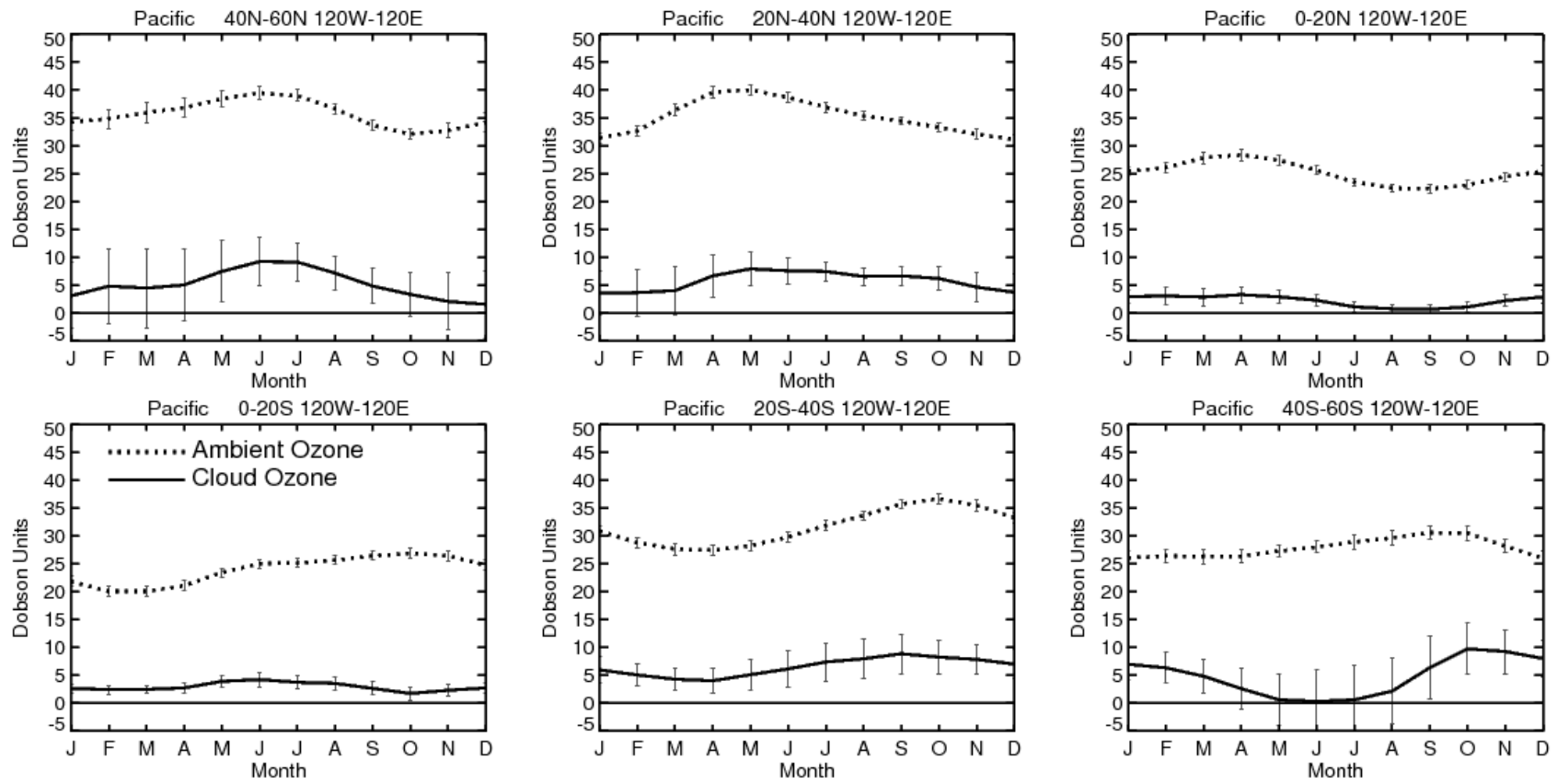

Fig. 5. Solid curves: line plots of CCD 12 -month annual cycles of cloud ozone averaged within six non-overlapping $20^{\circ}$ latitude bands in the Pacific. The latitude bands are (from upper left to lower right): $40-60^{\circ} \mathrm{N}, 20-40^{\circ} \mathrm{N}, 0-20^{\circ} \mathrm{N}, 0-20^{\circ} \mathrm{S}, 20-40^{\circ} \mathrm{S}$, and $40-60^{\circ} \mathrm{S}$. The Pacific averaging is for the longitude domain $120^{\circ} \mathrm{W}-120^{\circ} \mathrm{E}$ about the dateline. Dotted curves: same as solid curves but for background ambient tropospheric column ozone from OMI/MLS residual. These annual cycle time series are all derived by averaging together data for similar months over the six years. The vertical bars represent calculated $\pm 1 \sigma$ RMS standard error of mean. 

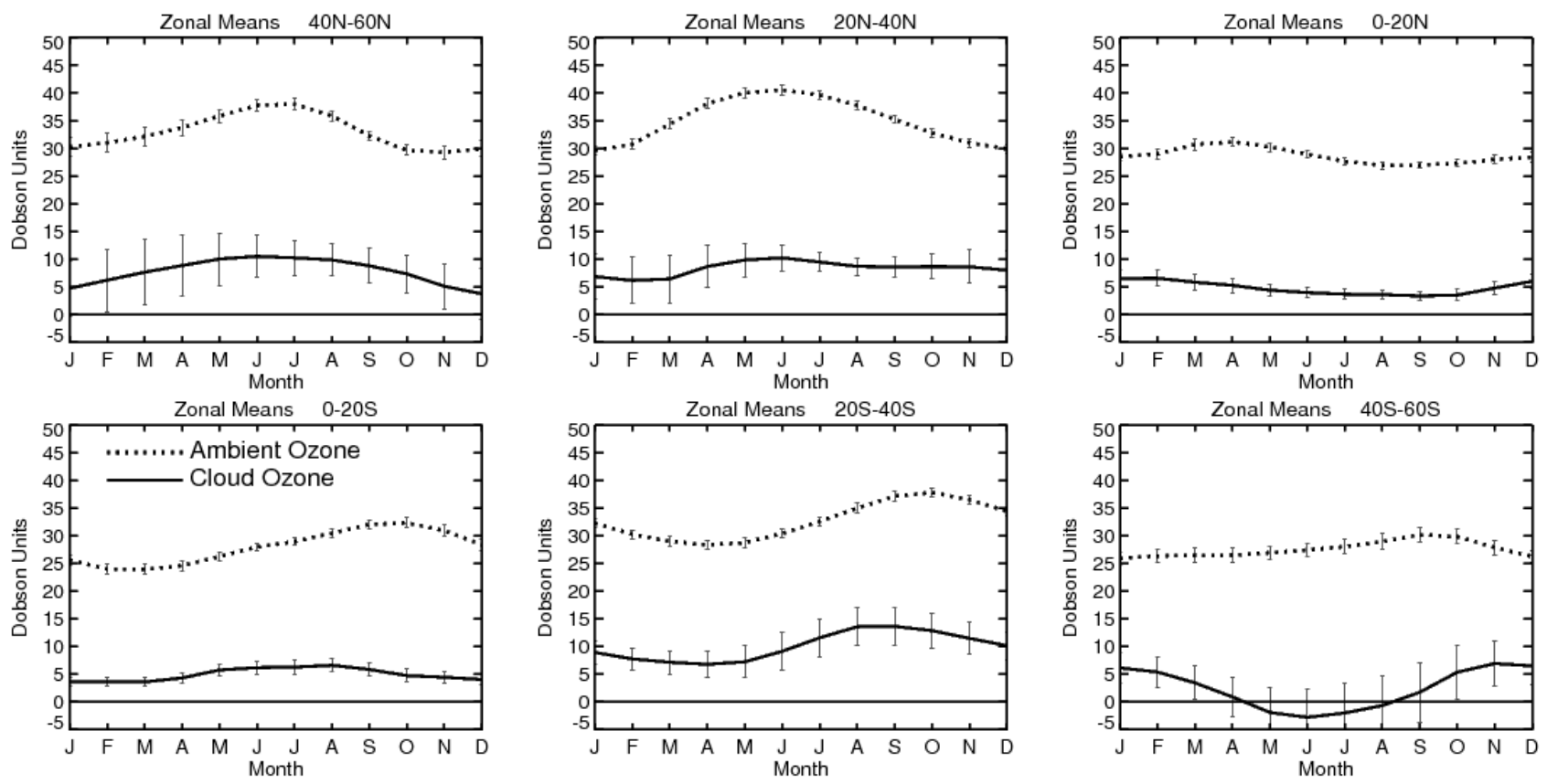

Fig. 6. Similar to Fig. 5 but for zonal mean measurements.
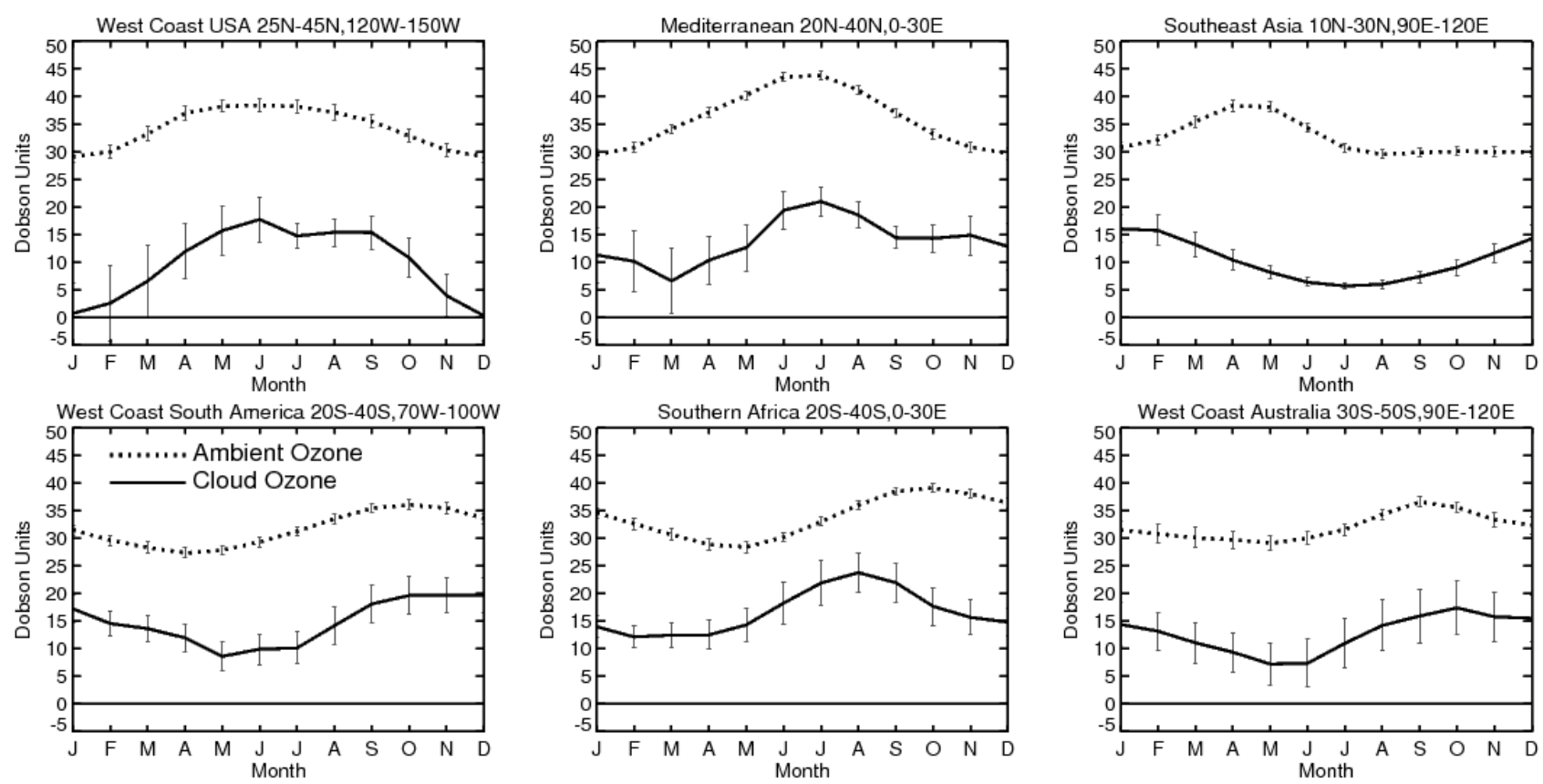

Fig. 7. Similar to Figs. 5 and 6 but instead for six broad regions of the globe where measured CCD cloud ozone is large with peak abundances of 15-20 DU. These six regions are from upper left to lower right (compare these regions with Fig. 4): West Coast of the USA, Mediterranean, Southeast Asia, West Coast of South America, Southern Africa, and West Coast of Australia.

Figure 6 is the same as Fig. 5 except that the time series were derived for zonal means rather than Pacific means. The conclusions for zonal means are similar to those discussed for Pacific means except that cloud ozone annual means are larger at most latitudes for zonal mean measurements. Fig- ure 7 shows more annual cycle line plot comparisons, but instead for six extra-tropical regions where cloud ozone often exceeds 5-20 DU (i.e., exceeding 50\% of ambient ozone in some months). It is inferred that these extra-tropical regions may be more polluted with boundary layer ozone injected 

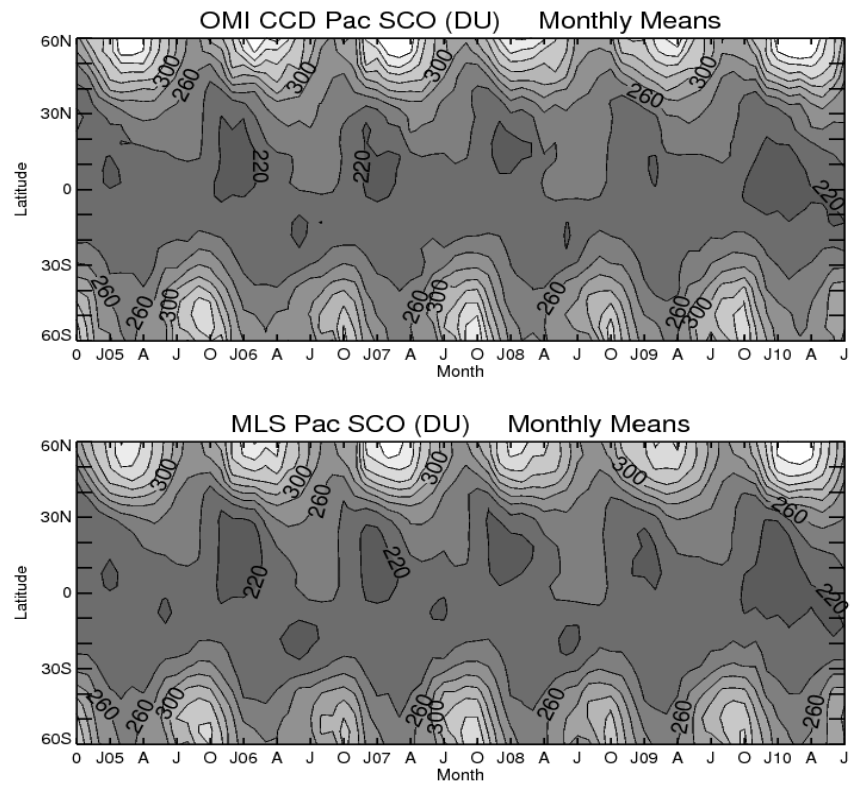

Fig. 8. Latitude versus month contour diagrams of monthly mean stratospheric column ozone (in Dobson Units) averaged over the Pacific $\left(120^{\circ} \mathrm{W}-120^{\circ} \mathrm{E}\right)$ from OMI CCD (top) and MLS (bottom). Dark to light shading designates smaller to higher column amounts, respectively. The contour values for both diagrams begin at 200 Dobson units and increment by 20 Dobson Units.

into the thick clouds from below and are more likely to have higher ozone concentrations in the upper troposphere in and above clouds coming from sources including STE and pollution. The annual cycles for cloud ozone and ambient ozone are not correlated for Southeast Asia and southern Africa in Fig. 7. For southern Africa, ambient ozone maximizes in September-October (same as the other two Southern Hemisphere regions in the figure), whereas cloud ozone maximizes earlier around August; August is a peak month for biomass burning in the southern Africa region.

The conclusions from Figs. 4-7 are that Pacific means and zonal means have nearly the same geophysical signatures in annual cycles for both the cloud ozone and ambient ozone, and also that most of the offset differences in Fig. 4 are recurring annual cycle features. Later in Sect. 4 we will show that after removing annual cycles from the data that interannual variability for the Pacific mean and zonal mean data products of both TCO and SCO from the CCD method are within a few DU from OMI/MLS residual ozone, not just in the tropics but extending to high latitudes.

\section{Inter-annual variability of tropospheric and stratospheric ozone}

In the study by Ziemke et al. (2005) the CCD measurements of TCO and SCO from combined Nimbus 7 and Earth Probe TOMS were extended to middle and high latitudes in the Pa-
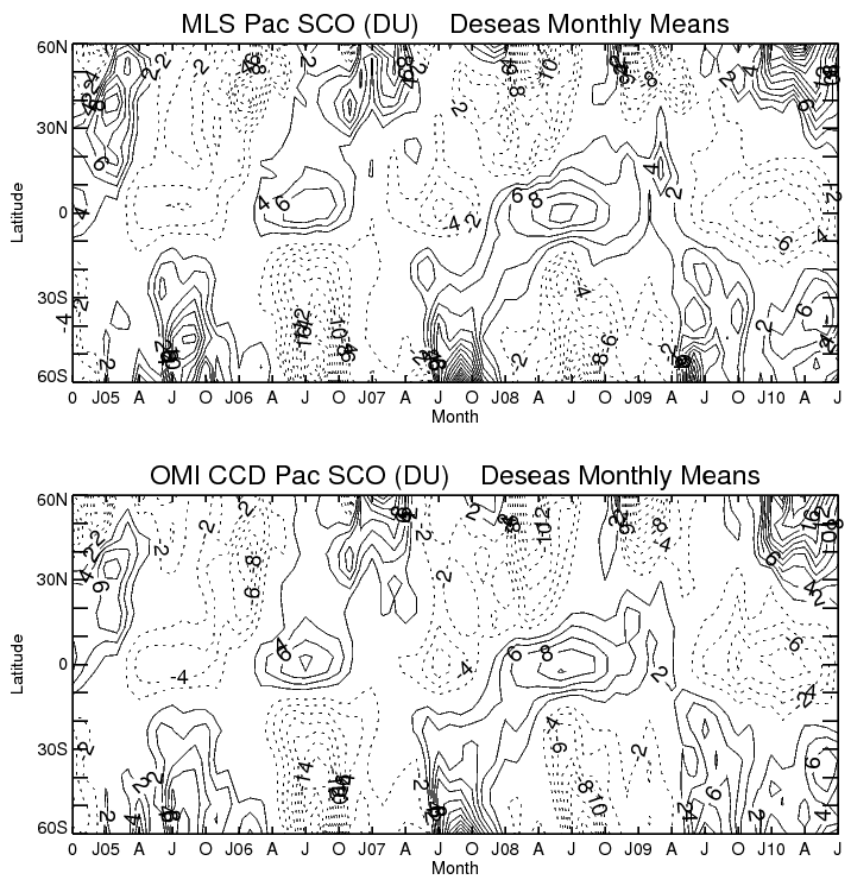

Fig. 9. Contour diagrams of the same stratospheric column ozone (in Dobson Units) plotted in Fig. 8, but instead with all of the data deseasonalized. Solid contours represent positive ozone anomalies and begin with +2 Dobson Units increasing in increments of +2 Dobson Units. Dotted contours represent negative ozone anomalies and begin with -2 Dobson Units decreasing in increments of -2 Dobson Units.

cific under the assumption that deep convective clouds with low boundary layer ozone conditions persist outside the tropics just as they do in the tropics. The CCD measurements of SCO were tested against SAGE II SCO for the time period 1984-2003. Despite sparse SAGE measurements those comparisons showed that SAGE and CCD SCO in the extratropics compared well in annual means and even better (to 2-4 DU differences) from the tropics to high latitudes when comparisons were made for summer months only.

We use the Aura MLS measurements of SCO which have greater spatial and temporal coverage than SAGE to evaluate how well the CCD method works outside tropical latitudes. Figure 8 compares latitude versus month contour diagrams of SCO averaged over the Pacific $\left(120^{\circ} \mathrm{W}-120^{\circ} \mathrm{E}\right)$ from OMI CCD (top) and MLS (bottom). SCO in middle and high latitudes for either OMI or MLS in Fig. 8 is largest in both hemispheres from winter into spring with large 80 100 DU peak-to-peak annual-cycle changes. There is indication of large inter-annual variability in both data sets from the tropics to high latitudes which includes an apparent QBO signal in the tropics with a period of about two years.

The SCO data in Fig. 8 were further deseasonalized to evaluate inter-annual changes (Fig. 9). Deseasonalization was accomplished by subtracting for each month a global 
monthly mean climatology value (determined by averaging similar months over the six-year record). The dominant interannual signature in Fig. 9 is the QBO which during the Aura record has about a 24-month period and is characteristically centered about the equator extending to high latitudes of both hemispheres.

The tropically driven QBO induces a global secondary circulation with opposite vertical wind fields between the tropics and extra-tropics (e.g., Andrews et al., 1987). Subsidence (ascent) of stratospheric air mass in equatorial latitudes associated with the QBO-induced circulation coincides with ascent (subsidence) of stratospheric air mass in the extratropics. In the tropics the subsidence of air mass driven by the QBO during the descending westerly phase (i.e., descending eastward zonal winds in the low-mid stratosphere) is seen in Fig. 9 as anomalous increases in tropical SCO that maximize around the months May-October for years 2006 and 2008. The QBO-induced down-welling circulation in the tropics coincides with opposite upwelling in the extra-tropics which is seen in Fig. 9 as anomalous reductions in SCO of $10-20$ DU in high latitudes of both hemispheres in winterspring months. The extra-tropical QBO variability appears clearer in the Southern Hemisphere because of a synchronous phase coupling between the Brewer Dobson Circulation annual component and the QBO which during the Aura record had about a 24-month cycle. The synchronous phase coupling between annual cycle and QBO in ozone and other stratospheric trace gases was studied by Dunkerton (2001). Dunkerton (2001) employed HALOE satellite measurements for an earlier time record of similar length (i.e., 1992-1999) and cites several studies relating to synchronization between QBO and annual cycle variability.

Toward the end of the record in Fig. 9 there is anomalously large SCO in the northern higher latitudes beginning around January 2010 for both OMI and MLS. These increases coincide with ozone decreases in the tropics associated with the descending easterly phase of the QBO. A recent study by Steinbrecht et al. (2011) combined ozonesondes from Hohenpeissenberg $\left(48^{\circ} \mathrm{N}, 11^{\circ} \mathrm{E}\right)$ and SCIAMACHY total ozone to conclude that these high values of ozone in 2010 were among the largest on record in northern latitudes during the last 20-25 yr. Their study attributes these large ozone enhancements to a coupling between the QBO and the Arctic Oscillation and North Atlantic Oscillation with the latter two oscillations being in an unusually persistent negative phase.

Time series of SCO corresponding to the data in Figs. 8 and 9 are plotted in Fig. 10 in $10^{\circ}$ latitude bands (indicated) for monthly means (left panels) and deseasonalized monthly means (right panels). Shown in all panels in Fig. 10 are Pacific averages for CCD (solid curves) and MLS (dotted curves). Despite seasonally varying offsets up to 5-10 DU between CCD and MLS in the left panels in Fig. 10, when the data are deseasonalized the month-to-month differences between the two ozone datasets is reduced for all latitude ranges. The deseasonalized time series in Fig. 10 for both residual methods show that the QBO-related signal in the Southern Hemisphere high latitudes is associated with interannual changes of $\sim 30 \mathrm{DU}$ or greater.

Pacific mean tropospheric ozone derived from the two residual methods is shown in Fig. 11. Figure 11 is the same as Fig. 10 but with TCO plotted rather than SCO. Shown in Fig. 11 are the original time series (left panels) and deseasonalized time series (right panels) for the same five latitude bands. There are obvious offset differences between the two methods in the left panels in Fig. 11 which are up to $\sim 10 \mathrm{DU}$ in some months. The offset differences for TCO in Fig. 11 are equal in magnitude (but of opposite sign) to the SCO offset differences in Fig. 10 since the same OMI total column ozone is used for both TCO time series. The deseasonalized TCO time series in the right panels do not have these offsets and track each other reasonably well.

Figures 9-11 suggest that inter-annual variability of $\mathrm{Pa}-$ cific mean SCO and TCO from the CCD method from the tropics to high latitudes compares closely to within a few DU with corresponding measurements from the OMI/MLS residual method. We will show that zonally averaged CCD abovecloud column ozone also compares close to zonal mean SCO from MLS.

Figure 12 shows contour diagrams of deseasonalized zonal mean SCO from MLS (top panel) and OMI CCD abovecloud column ozone (bottom panel). Comparison with Fig. 9 suggests that $\mathrm{SCO}$ from the two methods are closer for zonal means than for Pacific means.

Figure 13 plots temporal RMS values of the difference between CCD and MLS deseasonalized SCO time series for Pacific means (asterisks) and zonal means (triangles) as a function of latitude. (The RMS amplitudes for Pacific means and zonal means in Fig. 13 were calculated from OMI minus MLS differences of the data plotted in Figs. 9 and 12, respectively.) The RMS values in Fig. 13 for most latitudes are generally about $1-2 \mathrm{DU}$ and up to $\sim 2-3 \mathrm{DU}$ at higher latitudes. For zonal means RMS differences are about 0.5$1 \mathrm{DU}$ in the tropics to $\sim 1.5 \mathrm{DU}$ at mid-to-high latitudes. The RMS values in Fig. 13 for SCO are equivalent to the RMS amplitudes calculated for TCO. Zonal mean measurements of CCD deseasonalized SCO in Fig. 13 have slightly smaller RMS amplitudes than the Pacific mean measurements. The smaller RMS amplitudes for zonal mean measurements reflects reduced noise because of more gridded measurements and also that the offsets present between CCD and MLS SCO in all regions including the Atlantic are largely recurring seasonal cycle variations which are largely eliminated following deseasonalization of the data.

These comparisons between Aura OMI and MLS column ozone have given us greater confidence in the CCD measurements of tropospheric and stratospheric column ozone derived from previous TOMS retrievals. In the next section we discuss a long record of stratospheric and tropospheric ozone determined from combined TOMS and OMI records beginning 1979. 


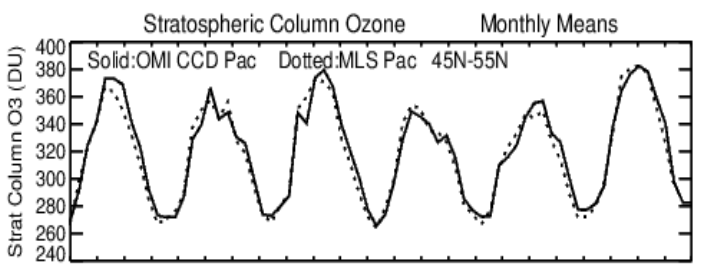

OJ05A J OJ06A J OJ07A J OJ08A J OJ09A J OJ10A

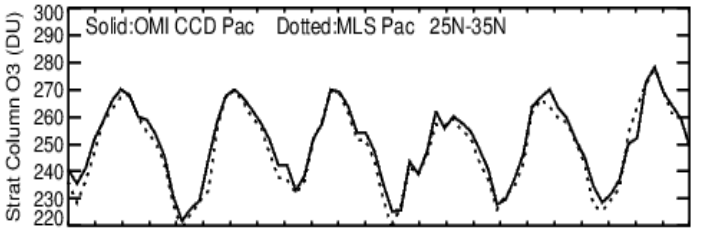

OJ05A J OJ06A J OJ07A J OJ08A J OJ09A J OJ10A J

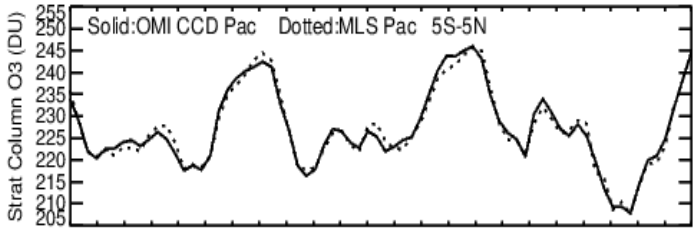

OJ05A J OJ06A J OJ07A J OJ08A J OJ09A J OJ10A

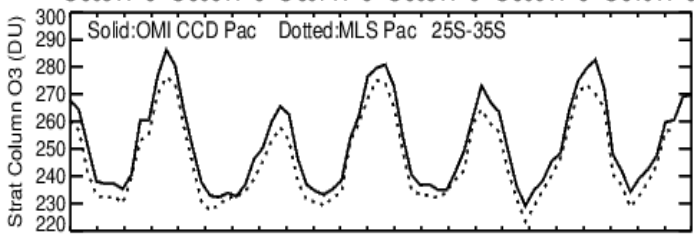

OJ05A J OJ06A J OJ07A J OJ08A J OJ09A J OJ10A
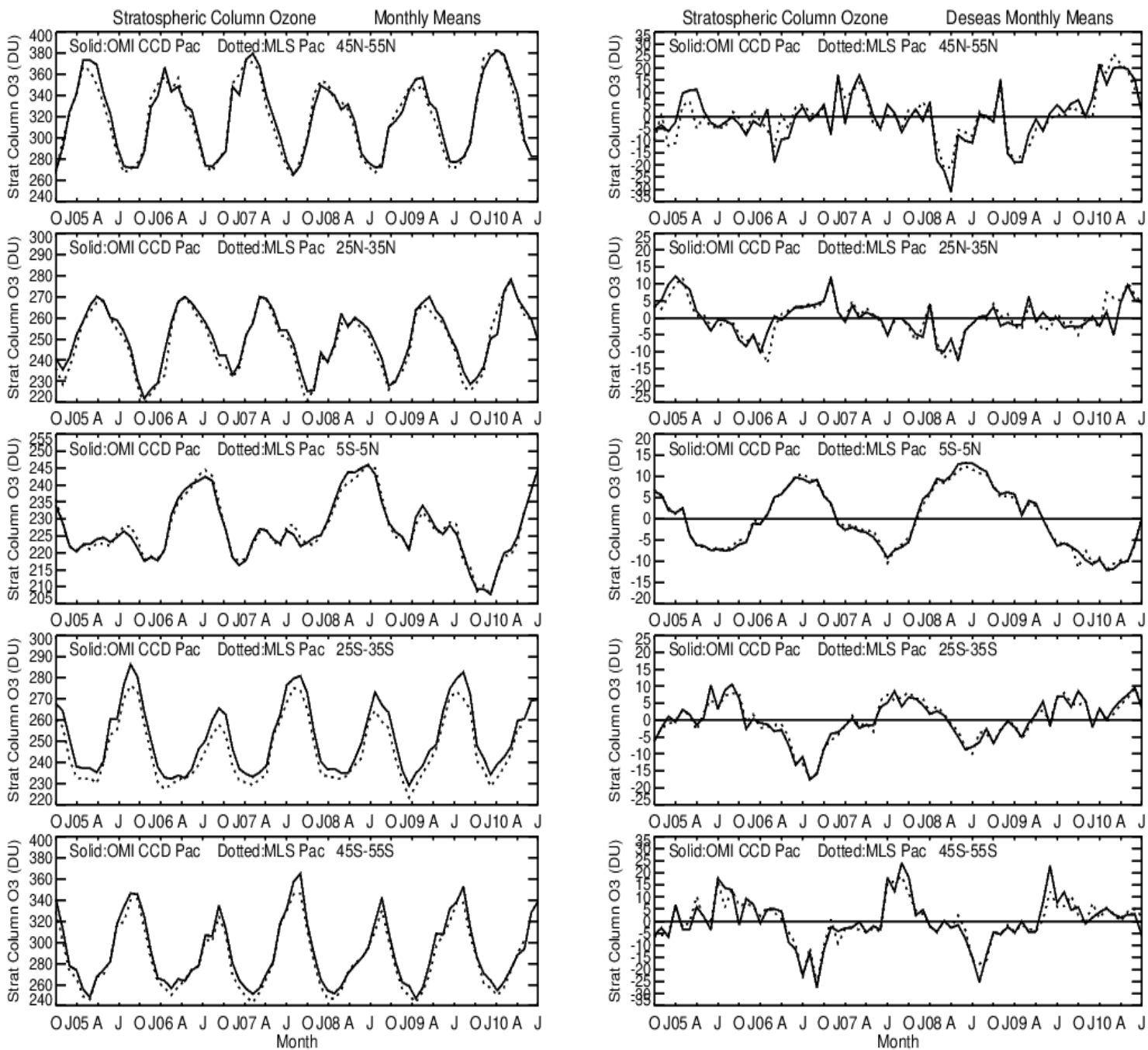

OJ05A J OJ06A J OJ07A J OJ08A J OJ09A J OJ10A J

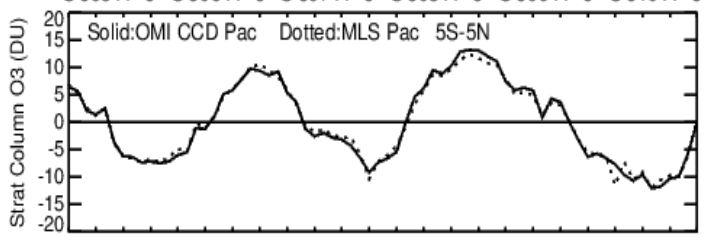

OJ05A J OJ06A J OJ07A J OJ08A J OJ09A J OJ10A J
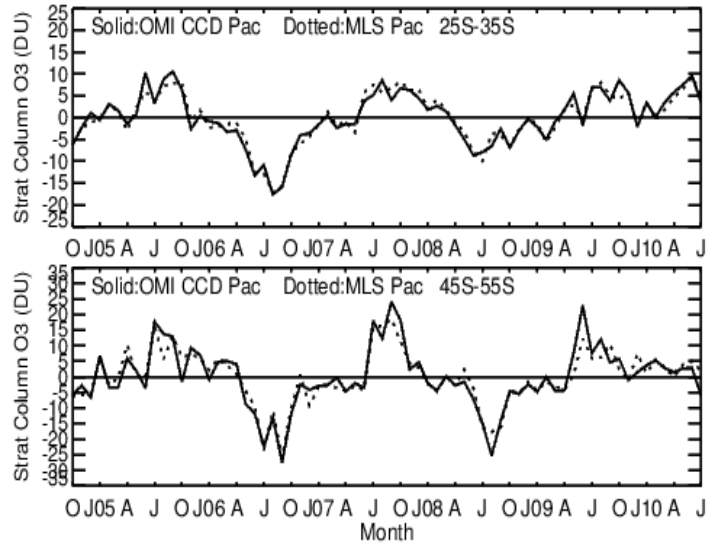

Fig. 10. (Left panels) Monthly averaged Pacific mean measurements of CCD SCO from OMI (solid curve) and MLS SCO (dotted curve) averaged over five indicated $10^{\circ}$ latitude bands. The Pacific mean represents data averaged over the combined eastern and western Pacific (i.e., longitude range $120^{\circ} \mathrm{W}$ to $120^{\circ} \mathrm{E}$ about the dateline). All measurements are in Dobson Units. (Right panels) Same as left panels but with the data deseasonalized.

\section{The TOMS+OMI ozone dataset}

We have developed an extended record of tropospheric and stratospheric column ozone spanning 1979-2010 by combining TOMS and OMI CCD measurements. The OMI data are appended with the earlier TOMS data used by Ziemke et al. (2005). It was noted in the data description section that the TOMS ozone uses the version 8 algorithm while OMI ozone uses the version 8.5 algorithm. Although there may be retrieval offsets existing between TOMS and OMI measurements because of different algorithms for the separate instruments, our analyses suggest that these offsets are not large and cannot be more than a few DU at most at any latitude. Offsets of only a few DU will adversely affect evaluation of inter-annual variability and calculated trends in tropospheric ozone, but such offsets have less relative impact for strato- spheric ozone. In the near future we plan to combine the TOMS and OMI stratospheric and tropospheric ozone data using only the single version 9 processed retrievals. We provide only a brief discussion of ozone trends and inter-annual (QBO) variability in tropospheric ozone for the 1979-2010 data record.

\subsection{Quasi-Biennial Oscillation signals in tropical ozone}

Although it is well known that there exists a large QBO variability in stratospheric ozone, there is also evidence of a QBO in tropospheric ozone. Ziemke and Chandra (1999) first detected a possible QBO in tropospheric ozone using Nimbus-7 TOMS measurements for the 1979-1993 record. A later study by Chandra et al. (2002) combined Nimbus7 TOMS with Earth Probe TOMS and found a consistent 

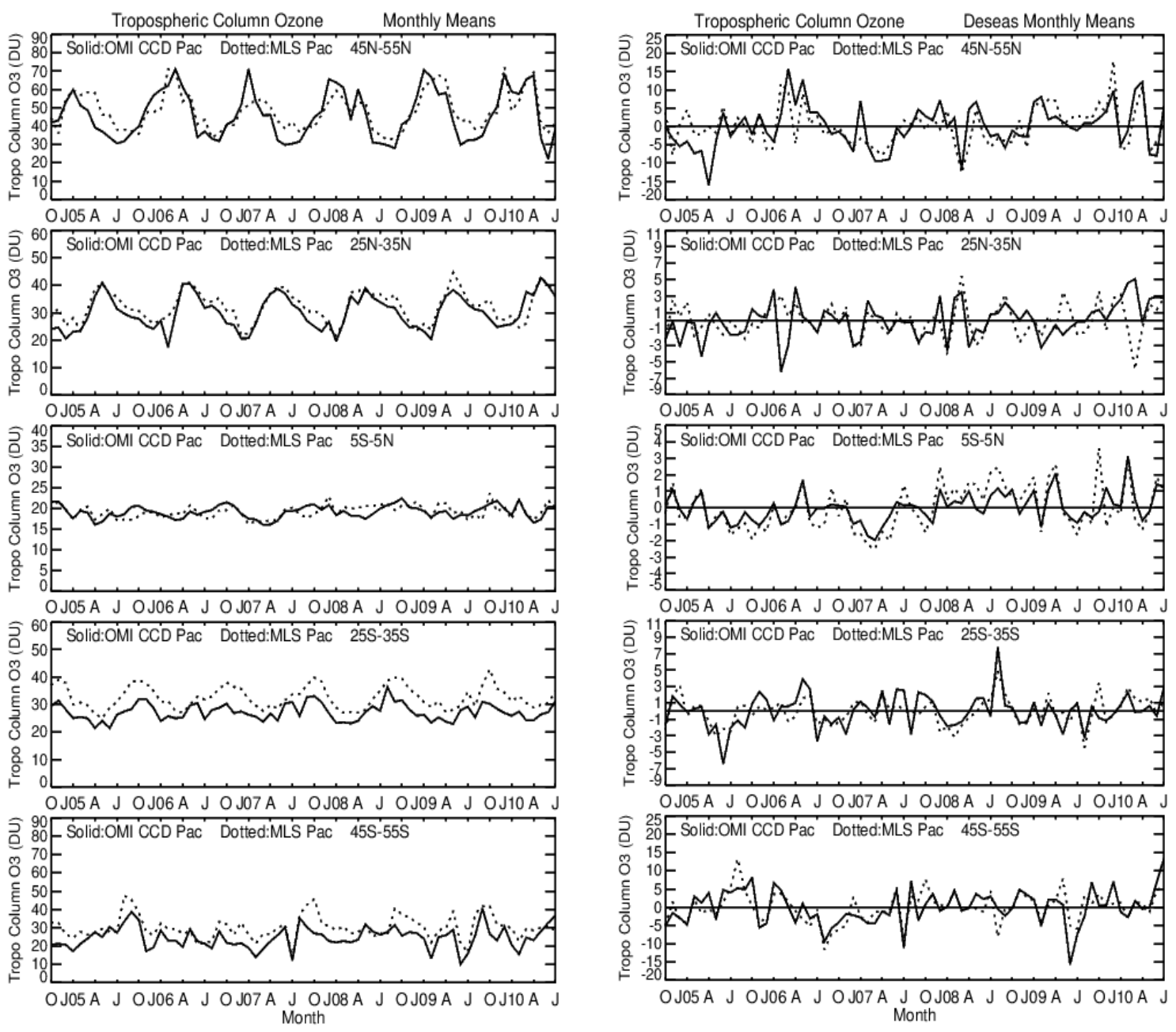

Fig. 11. (Left panels) Monthly averaged Pacific mean measurements of CCD TCO from OMI (solid curves) and OMI/MLS TCO (dotted curves) averaged over five indicated $10^{\circ}$ latitude bands. The Pacific mean represents data averaged over the combined eastern and western Pacific (i.e., longitude range $120^{\circ} \mathrm{W}$ to $120^{\circ} \mathrm{E}$ about the dateline). All measurements are in Dobson Units. (Right panels) Same as left panels but with the data deaseasonalized.

QBO in tropospheric ozone over a longer record of 19792000. The QBO in tropospheric ozone for these studies was clearer to detect in the Atlantic region as opposed to the Pacific as there is additional inter-annual variability in the Pacific related to ENSO events. The QBO in tropospheric ozone was shown to be negatively correlated with the QBO in SCO. It was postulated by Ziemke and Chandra (1999) that a possible source for the QBO signal could be an upper tropospheric ozone photochemistry response from the QBO in stratospheric ozone. However, the measured tropospheric signal was larger than predicted by photochemical modeling and it was concluded by Ziemke and Chandra (1999) that the source for the QBO signal in tropospheric ozone was most likely of dynamical origin. Lee et al. (2010) have reached these same conclusions based upon balloon sonde data from the Southern Hemisphere Additional Ozonesondes (SHADOZ) network. Their analyses of the sonde tempera- ture and ozone measurements suggest that the QBO signal in tropospheric ozone extends down to about mid-troposphere and is of dynamical origin.

Figure 14 plots $50 \mathrm{hPa}$ monthly zonal winds from Singapore $\left(1^{\circ} \mathrm{N}, 104^{\circ} \mathrm{E}\right)$ (dotted curve) and deseasonalized tropospheric ozone (solid curve) averaged in the equatorial Atlantic $\left(5^{\circ} \mathrm{S}-5^{\circ} \mathrm{N}, 60^{\circ} \mathrm{W}-60^{\circ} \mathrm{E}\right)$. There are two data gaps present in the time series in Fig. 14. The first gap is several years of non-existing measurements between Nimbus 7 and Earth Probe TOMS periods. The second gap in Fig. 14 represents Earth Probe CCD measurements which have been conservatively flagged as missing after year 2000 for questionable data quality. Tropospheric ozone in Fig. 14 was additionally smoothed using a low-pass digital filter as described in the figure caption.

Comparison of the $50 \mathrm{hPa}$ zonal winds and tropospheric ozone in Fig. 14 indicates a persistent negative correlative 

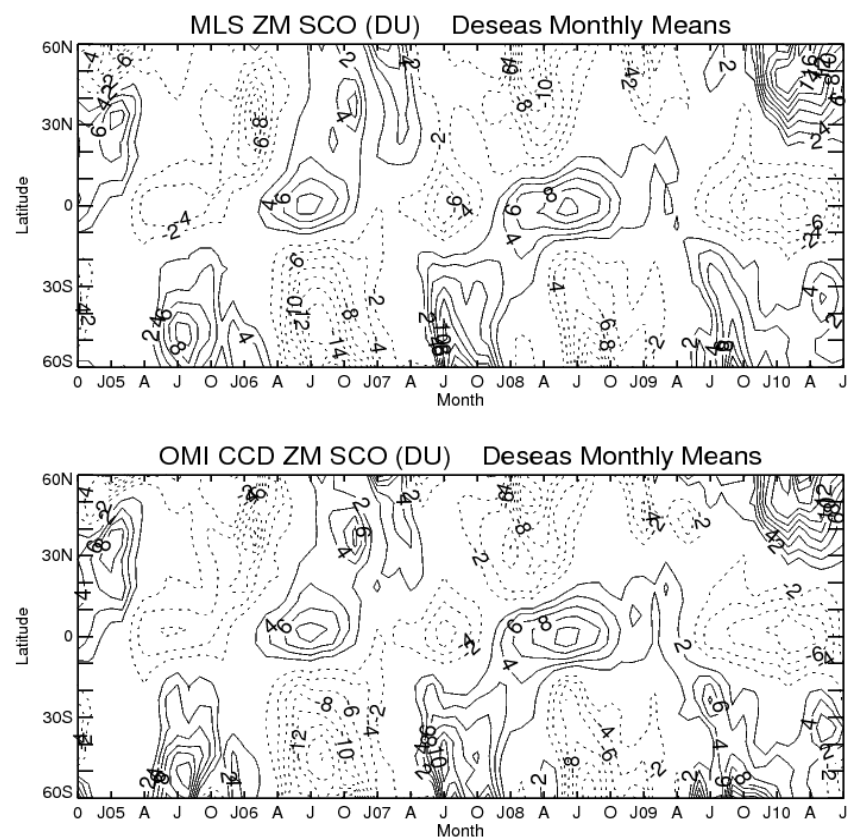

Fig. 12. Same as Fig. 9, but instead for zonal means rather than Pacific means.

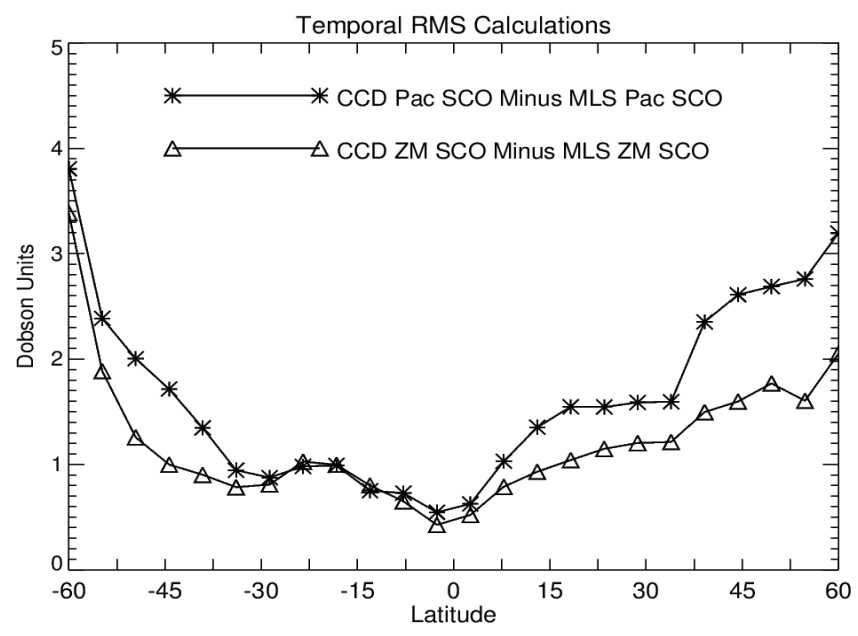

Fig. 13. Calculated temporal RMS values (in Dobson Units) of the difference between CCD and MLS deseasonalized SCO time series for Pacific means (asterisks) and zonal means (triangles) as a function of latitude. These RMS amplitudes were calculated from the difference between the data plotted in Figs. 9 and 12, respectively.

relationship over the long 32-yr multi-instrument record. The QBO signal in tropospheric ozone for the 1979-1993 Nimbus-7 TOMS period in Fig. 14 is larger than during the latter EP TOMS and OMI periods. Peak-to-peak differences in ozone for the Nimbus-7 record are $\sim 4-7$ DU compared to $\sim 2-4 \mathrm{DU}$ for the latter years. There are some years in Fig. 14 where the wind/ozone negative correlation relation is not evident. One case occurs around 1990-1991 (coinciding

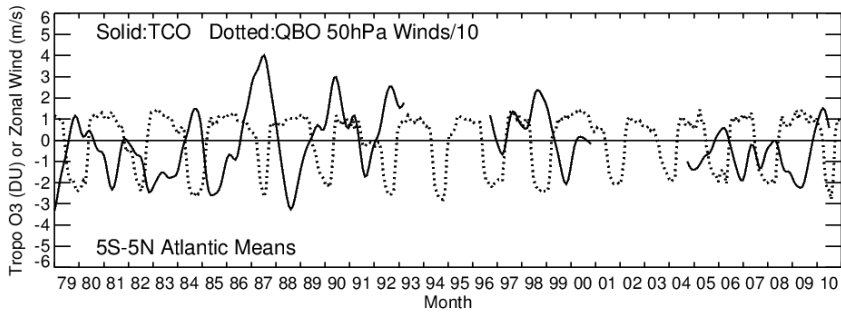

Fig. 14. Tropospheric column ozone from the CCD method in Dobson Units (solid curve) plotted versus $50 \mathrm{hPa}$ zonal winds from Singapore $\left(1^{\circ} \mathrm{N}, 104^{\circ} \mathrm{E}\right)$ in units $\mathrm{m} \mathrm{s}^{-1}$ but divided by 10 for scaling (dotted curve). The ozone time series was averaged over the equatorial Altantic region $\left(5^{\circ} \mathrm{S}-5^{\circ} \mathrm{N}, 60^{\circ} \mathrm{W}-60^{\circ} \mathrm{E}\right)$. The ozone time series was deseasonalized and detrended, and then smoothed using a recursive low-pass digital filter with one-half filter response at 12-month period (filter response of about $0.8-0.9$ for 24-36 month QBO time periods).

with the July 1991 Mt. Pinatubo eruption), and another case is in 1997-1998 during an intense tropical El Nino event.

We conclude from the TOMS+OMI 32-yr record that there appears to be a persistent QBO signal in tropospheric ozone with peak-to-peak amplitudes varying from about $2 \mathrm{DU}$ up to $7 \mathrm{DU}$. This evidence further strengthens claims from previous studies of a QBO in tropospheric ozone. We note that Lee et al. (2010) from ozonesonde analyses found maximum QBO signal in tropospheric ozone profile measurements of about 8 ppbv (equivalent to $\sim 2-3 \mathrm{DU}$ in upper troposphere) which is not inconsistent with the signal amplitudes that we find from the TOMS+OMI combined record.

\subsection{Ozone trends}

Trends in tropospheric and stratospheric ozone were calculated by Ziemke et al. (2005) for a 25-yr record (19792003) of TOMS CCD measurements in the Pacific. Ziemke et al. (2005) found that trends in tropospheric ozone were near zero most everywhere but marginally positive ( +2 DU to +3 DU decade ${ }^{-1}$ ) in mid-latitudes of both hemispheres. Trends in stratospheric column ozone were also near zero in the tropics but large and negative $(\sim-10$ to $-14 \mathrm{DU} \mathrm{decade}^{-1}$ ) in the mid-high latitudes of both hemispheres. We have made similar calculations of trends using the extended TOMS+OMI 32-yr record. The results presented are limited to stratospheric ozone trends; tropospheric ozone trends for the 32-yr record are not substantially different from Ziemke et al. (2005) based on a shorter data record.

Figure 15 shows calculated trends (both DU-decade ${ }^{-1}$ and percent-decade ${ }^{-1}$ units) in Pacific mean stratospheric column ozone for the Nimbus-7 15-yr (1979-1993) beginning record (bottom dotted curve), and 15-yr (1996-2010) ending record (top dashed curve). For comparison, the average of these two trend curves is also shown (middle solid curve). The trends in Fig. 15 for the two 15-yr datasets were 


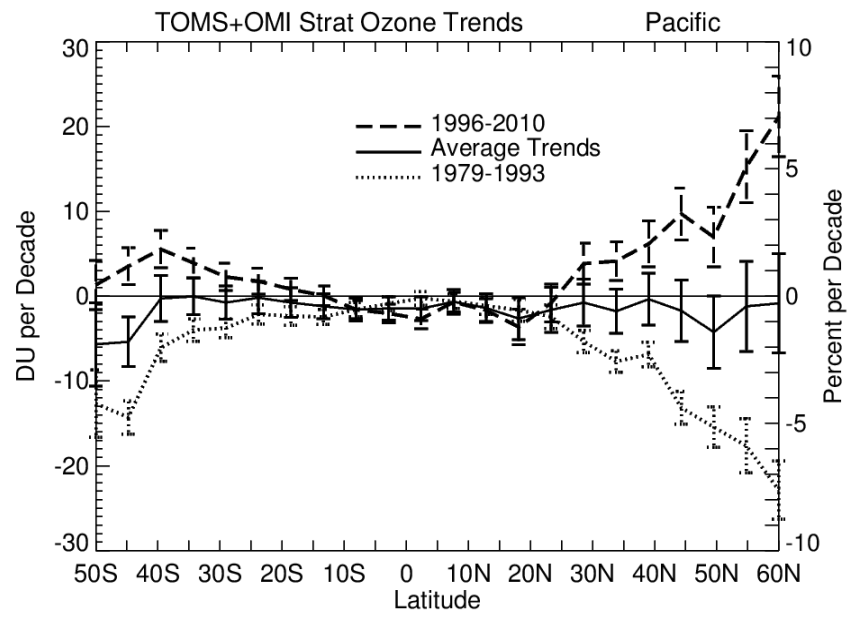

Fig. 15. Trends of CCD stratospheric column ozone for the 19791993 beginning 15-yr record (bottom dotted curve) and 1996-2010 ending 15-yr record (top dashed curve). The trend units for the left vertical axis are DU decade ${ }^{-1}$ with the right vertical axis units given as percent decade ${ }^{-1}$. As comparison, trends for these two 15-yr records are averaged together (middle solid curve). Trends were derived for the two $15-\mathrm{yr}$ records using a linear multivariae regression model (see text). All data were averaged over the Pacific $\left(120^{\circ} \mathrm{W}\right.$ to $120^{\circ} \mathrm{E}$ about dateline) within $5^{\circ}$ latitude bands. Vertical bars indicate $\pm 2 \sigma$ annual mean trend uncertainties calculated from the regression model. The trend uncertainty bars include an additional $2 \mathrm{DU}(2 \sigma)$ long-term inter-instrument calibration/drift uncertainty. Values of $2 \sigma$ for the averaged trends were derived by taking the square root of the sum of the variances for the two $15-\mathrm{yr}$ record variances $\times 2$.

calculated for monthly means using the multivariate regression model of Ziemke et al. (2005). This model included regression fits for combined linear trend, seasonal cycle, QBO, solar cycle, and ENSO. The latitude range in Fig. 15 coincides with the trend figures shown by Ziemke et al. (2005) in which there are too few Nimbus 7 CCD monthly measurements pole-ward of $50^{\circ} \mathrm{S}$ for seasonal trend analysis. The two 15 -yr beginning and ending periods were chosen based on plotting of time series such as in Fig. 16 (discussed later) which has a characteristic "V"-shaped time dependence after removing solar signal.

It is evident in Fig. 15 that the strong negative trends in stratospheric ozone outside the tropics for the 15 -yr beginning period (bottom dotted curve) are nearly negated by trends for the 15-yr ending record (top dashed curve). Most of the change in trends and global increase in ozone over the last $15 \mathrm{yr}$ lies in the Northern Hemisphere extending from the subtropics to high latitudes. Area weighting of the extratropical trend differences (i.e., ending minus beginning 15yr record trends) in Fig. 15 for latitudes $50^{\circ} \mathrm{S}$ to $50^{\circ} \mathrm{N}$ indicates $2 / 3$ of the change in stratospheric ozone lies in the Northern Hemisphere. Trends of 10 to $20 \mathrm{DU}$ decade $^{-1}$ in the mid-high latitudes in Fig. 15 correspond to trends of approxi-
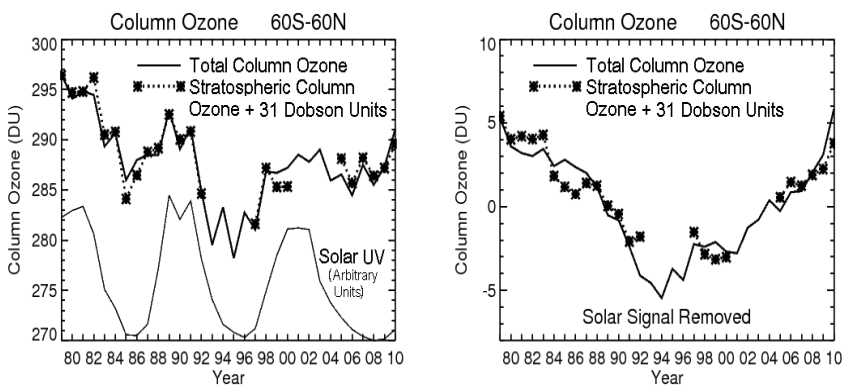

Fig. 16. (Left) Annual mean time series of MOD total column ozone (thick solid curve along top), TOMS+OMI CCD measurements of stratospheric column ozone (thick dotted curve along top), and solar $F 10.7 \mathrm{~cm}$ radio flux (thin solid curve along bottom) which has been rescaled for plotting. Stratospheric column ozone has had 31 Dobson Units added for visualization in plotting with total column ozone. Both ozone time series represent area-weighted measurements lying between latitudes $60^{\circ} \mathrm{S}$ and $60^{\circ} \mathrm{N}$. The MOD total column ozone time series was derived from zonal means whereas the CCD stratospheric column ozone time series was derived from Pacific means. (Right) Similar to ozone plotted in the left panel except that time averages have been removed and the 11-yr solarcycle signals in the two ozone time series have been extracted by linear regression. The regression model used to remove $11-\mathrm{yr}$ solar cycle variability in the two ozone time series is $(t$ is year in$\operatorname{dex})$ : Ozone $(t)=C \cdot \operatorname{Solar}(t)+\varepsilon(t)$ where $C$ and is a constant, $S o$ lar is solar $F 10.7 \mathrm{~cm}$ annual mean time series (with time average removed) and $\varepsilon=$ model residual error. (The two derived residual series $\varepsilon(t)$ are plotted in the right panel.) A 3-yr running average was applied to both time series in the right panel for smoothing.

mately 3 to $6 \%$ decade $^{-1}$, respectively. Inter-instrument calibration offsets and/or drifts cannot explain the large changes in trends in the extra-tropics in Fig. 15 between the two time records. That is, calibration errors are not generally dependent of latitude, and although large trend changes are measured in the extra-tropics in Fig. 15, trends in the tropics remain near zero for both time records.

A complicating factor in assessing global stratospheric ozone recovery and turnaround period of stratospheric ozone loss is solar cycle variability. Figure 16 (left panel) shows annual mean time series of CCD stratospheric ozone (stars) plotted with merged total column ozone from the NASA merged ozone datasets (MOD) webpage http://acdb-ext.gsfc. nasa.gov/Data_services/merged/. Both time series represent column ozone area averaged between $60^{\circ} \mathrm{S}$ and $60^{\circ} \mathrm{N}$. The MOD total column ozone time series in Fig. 16 was derived from zonal means whereas the CCD stratospheric column ozone time series was derived from Pacific means. It was shown Ziemke et al. (2005) that trends in total column ozone and stratospheric column ozone are nearly identical for zonal means and Pacific means either globally or as function of latitude. For CCD stratospheric ozone a constant $31 \mathrm{DU}$ was added to the time series for plotting with total column ozone. This $31 \mathrm{DU}$ accounts for the abundance of 
tropospheric ozone. Along the bottom in Fig. 16 as a proxy of solar UV variability is solar $F 10.7 \mathrm{~cm}$ radio flux time series (e.g., Jackman et al., 1996, and references therein).

One cannot readily identify a turnaround period in the ozone time records in the left panel of Fig. 16 because of a dominant solar cycle present. In the right panel of Fig. 16 we have removed most solar cycle variability in both ozone time series using regression (discussed in figure caption). With solar variability removed we identify a turnaround period occurring in the mid-1990's for stratospheric and total column ozone. We can also conclude from the right panel in Fig. 16 that tropospheric ozone does not indicate substantial decadal changes.

Several previous studies have done similar analyses as in Figs. 15-16 but were based upon shorter ozone records. We mention some of these studies which have relevant impact for our results. Weatherhead and Anderson (2006) investigated signatures of stratospheric ozone recovery from MOD total ozone for 1979-2005. Their Fig. 3 is similar to Fig. 15 and showed a similar signature of turnaround in trends over the final $10 \mathrm{yr}$ of their ozone record (1996-2005). They concluded that there was a signature of recovery occurring but it may have been influenced by other natural variability involving changes in temperature and dynamical forcing. A number of other studies have suggested that the early record of the turnaround in trends was influenced by natural increase caused by change in dynamics, particularly in the Northern Hemisphere extra-tropics (e.g., Krizan and Lastovicka, 2005; Harris et al., 2008; WMO, 2011). Stolarski and Frith (2006) showed a figure (their Figure 7) which is similar to the left panel of our Fig. 16 except that they instead plotted monthly mean MOD total column ozone and for a shorter time record of October 1978-June 2006. Their Fig. 7 also shows an obvious positive correlation of total ozone with solar UV for the Nimbus 7 and Earth Probe periods and with a "leveling off" period of ozone in the final years beginning in the late 1990's despite solar UV decreasing substantially during that time period. An obvious implication of this leveling off period during solar UV decrease is that there may be large stratospheric ozone recovery occurring following the late 1990's which overwhelms downward solar forcing and dynamical effects. Now with several more years of additional ozone measurements than previous studies, stratospheric column ozone and total column ozone in Fig. 16 (right panel) continue to show increases. Over the next few years solar UV forcing will reach maximum and should tend to increase global ozone levels further. It will be interesting to see in the next few years whether or not global stratospheric ozone continues to increase and by how much.

Among the first papers to evaluate global ozone trends and recovery turnaround in models and satellite measurements was Jackman et al. (1996) which used a 2-D chemical transport model. Interestingly, their model predicted a turnaround in the mid-1990's and recovery of ozone by 2010 similar to the amounts present in the mid-1980's. These features are both present in the measurements in the right panel of Fig. 16. Similar figures comparing total column ozone from models and measurements have been shown recently in the 2010 WMO report and by Oman et al. (2010, and references therein). Most of the recent models predict a turnaround occurring around year 2000 with largely varying recovery time periods. Many of the models predict a longer ozone recovery to 1980 's levels by year 2020 or later.

The Montreal Protocol was an international treaty initiated in 1987 to reduce worldwide ozone destroying substances such as chlorofluorocarbons and Bromine compounds. As a result of this treaty, since 1989 there has been a dramatic global reduction in these substances and a turnaround in ozone trends. After accounting for solar UV forcing the 32 -yr record indicates a turnaround in stratospheric ozone loss in the mid-1990's with recent ozone levels comparable to amounts present around year 1980. These measurements seem to suggest a faster stratospheric ozone recovery occurring than predicted by many of the recent models.

\section{Summary and conclusions}

The convective-cloud differential (CCD) method is the most basic form of the "cloud slicing" technique. This method generates gridded measurements of TCO and SCO in the tropics and also Pacific mean and zonal mean TCO and SCO extending to high latitudes. The CCD method is assessed using Aura OMI and MLS ozone measurements for the period October 2004 through July 2010. TCO and SCO from the CCD method are compared with corresponding OMI/MLS residual measurements in which MLS ozone profiles are used to calculate SCO. The Aura OMI/MLS data provide greatly improved temporal and spatial coverage for evaluating the CCD measurements as previous validation efforts involved sparse data from SAGE and HALOE (for SCO) and ozonesondes (for TCO).

The analyses indicate that the CCD and OMI/MLS gridded TCO products in the tropics agree to within one DU offset with a mean RMS difference of about 3 DU. RMS differences between these two datasets for inter-annual variations in the Pacific are about 0.5-2.5 DU for either TCO or $\mathrm{SCO}$ over most latitudes ranging from the tropics to high latitudes. (RMS differences for TCO are the same as for SCO since total column ozone from OMI is used for both residual methods.) RMS differences for either zonal mean TCO or zonal mean SCO vary from about $0.5-1 \mathrm{DU}$ in the tropics to $\sim 1.5 \mathrm{DU}$ at mid-to-high latitudes.

The Aura OMI/MLS ozone data have given us greater confidence in the CCD measurements of tropospheric and stratospheric ozone derived from previous TOMS measurements. This is important for extending the TOMS data with more recent OMI data to develop a long record of tropospheric and stratospheric ozone for evaluating decadal changes. We have developed from TOMS and OMI measurements a long 
32-yr (1979-2010) dataset of tropospheric and stratospheric ozone. The analyses of these time series show that the quasibiennial oscillation (QBO) is the dominant source of interannual variability of stratospheric ozone. During the Aura record the QBO variability in stratospheric ozone was of a 24-month periodicity and was clearest throughout the Southern Hemisphere extending to high latitudes. Both CCD and MLS measurements show QBO-related inter-annual variability of stratospheric ozone in the Southern Hemisphere of 3040 DU. The 32-yr dataset also indicates a QBO signal in tropospheric ozone with peak-to-peak amplitudes varying from about $2 \mathrm{DU}$ up to $7 \mathrm{DU}$. These results further strengthen evidence of a QBO signal in tropospheric ozone as suggested in previous studies based upon much shorter time record measurements from SHADOZ ozonesondes and TOMS satellite ozone.

Trend analysis of the 32-yr record dataset suggests a turnaround in global stratospheric column ozone loss in the mid-1990's with current ozone levels comparable to the mid1980's. After accounting for solar UV forcing the ozone levels are now similar to about year 1980. Our analyses show that most of the trend turnaround occurred in the Northern Hemisphere extending from the subtropics to high latitudes. The last $15 \mathrm{yr}$ of record (1996-2010) indicates nearly opposite positive trends in both hemispheres compared to the first $15 \mathrm{yr}$ of record (1979-1994). The measurements suggest that stratospheric ozone levels comparable to 1980 or earlier may be possible within the next several years as the 11-yr solar cycle UV reaches peak production of stratospheric ozone.

The trends of stratospheric ozone are generally consistent with the prediction of past and current chemistry-climate models, however many of these models predict a turnaround occurring around year 2000 and longer ozone recovery to mid-1980's levels by year 2020 or later. Regardless of discrepancies, our results suggest substantial recovery now occurring in global stratospheric ozone largely as a result of the Montreal Protocol.

Acknowledgements. The authors thank the Aura MLS and OMI instrument and algorithm teams for the extensive satellite measurements used in this study. We thank S. M. Frith and R. D. Stolarski for providing the merged total ozone data set used in our analyses. We also thank editor Tim Dunkerton for his valuable comments and suggestions about the manuscript and to thank the two anonymous referees. The comments from all involved have been very beneficial in improving the paper. OMI is a Dutch-Finnish contribution to the Aura mission. Funding for this research was provided in part by NASA NNH07ZDA001N-AST.

Edited by: T. J. Dunkerton

\section{References}

Andrews, D. G., Holton, J. R., and Leovy, C. B.: Middle Atmosphere Dynamics, Academic, San Diego, Calif., 489 pp., 1987.

Chandra, S., Ziemke, J. R., Bhartia, P. K., and Martin, R. V.: Tropical tropospheric ozone: Implications for dynamics and biomass burning, J. Geophys. Res., 107, 4188, doi:10.1029/2001JD000447, 2002.

Chandra, S., Ziemke, J. R., and Martin, R. V.: Tropospheric ozone at tropical and middle latitudes derived from TOMS/MLS residual: Comparison with a global model, J. Geophys. Res., 108, 4291, doi:10.1029/2002JD002912, 2003.

Dunkerton, T. J.: Quasi-Biennial and Sub-biennial Variations of Stratospheric Trace Constituents Derived from HALOE Observations, J. Atmos. Sci., 58, 7-25, 2001.

Fishman, J. and Larsen, J. C.: Distribution of total ozone and stratospheric ozone in the tropics: Implications for the distribution of tropospheric ozone, J. Geophys. Res., 92, 6627-6634, 1987.

Fishman, J., Watson, C. E., Larsen, J. C., and Logan, J. A.: Distribution of tropospheric ozone determined from satellite data, J. Geophys. Res., 95, 3599-3617, 1990.

Froidevaux, L., Jiang, Y. B., Lambert, A., Livesey, N. J., Read, W. G., Waters, J. W., Browell, E. V., Hair, J. W., Avery, M. A., McGee, T. J., Twigg, L. W., Sumnicht, G. K., Jucks, K. W., Margitan, J. J., Sen, B., Stachnik, R. A., Toon, G. C., Bernath, P. F., Boone, C. D., Walker, K. A., Filipiak, M. J., Harwood, R. S., Fuller, R. A., Manney, G. L., Schwartz, M. J., Daffer, W. H., Drouin, B. J., Cofield, R. E., Cuddy, D. T., Jarnot, R. F., Knosp, B. W., Perun, V. S., Snyder, W. V., Stek, P. C., Thurstans, R. P., and Wagner, P. A.: Validation of Aura Microwave Limb Sounder stratospheric ozone measurements, J. Geophys. Res., 113, D15S20, doi:10.1029/2007JD008771, 2008.

Folkins, I., Braun, C., Thompson, A. M., and Witte, J. C.: Tropical ozone as an indicator of deep convection, J. Geophys. Res., 107, 4184, doi:10.1029/2001JD001178, 2002.

Harris, N. R. P., Kyrö, E., Staehelin, J., Brunner, D., Andersen, S.B., Godin-Beekmann, S., Dhomse, S., Hadjinicolaou, P., Hansen, G., Isaksen, I., Jrrar, A., Karpetchko, A., Kivi, R., Knudsen, B., Krizan, P., Lastovicka, J., Maeder, J., Orsolini, Y., Pyle, J. A., Rex, M., Vanicek, K., Weber, M., Wohltmann, I., Zanis, P., and Zerefos, C.: Ozone trends at northern mid- and high latitudes - a European perspective, Ann. Geophys., 26, 1207-1220, doi:10.5194/angeo-26-1207-2008, 2008.

Jackman, C. H., Fleming, E. L., Chandra, S., Considine, D. B., and Rosenfield, J. E.: Past, present, and future modeled ozone trends with comparisons to observed trends, J. Geophys. Res., 101, 28753-28767, 1996.

Kley, D., Crutzen, P. J., Smit, H. G. J., Vomel, H., Oltmans, S. J., Grassl, H., and Ramanathan, V.: Observations of near-zero ozone concentrations over the convective Pacific: Effects on air chemistry, Science, 274, 230-232, 1996.

Krizan, P. and Lastovicka, J.: Trends in positive and negative ozone laminae in the Northern Hemisphere, J. Geophys. Res., 110, D10107, doi:10.1029/2004JD005477, 2005.

Lee, S., Shelow, D. M., Thompson, A. M., and Miller, S. K.: QBO and ENSO variability in temperature and ozone from SHADOZ, 1998-2005, J. Geophys. Res., 115, D18105, doi:10.1029/2009JD013320, 2010.

Levelt, P. F., Hilsenrath, E., Leppelmeier, G. W., van den Oord, G. H. J., Bhartia, P. K., Tamminen, J., de Haan, J. F., and Veefkind, J. 
P.: Science objectives of the Ozone Monitoring Instrument, IEEE

T. Geophys. Remote Sens., 44, 1199-1208, 2006.

Liu, X., Newchurch, M. J., Loughman, R., and Bhartia, P. K.: Errors resulting from assuming opaque Lambertian cloud surfaces in TOMS ozone retrieval, J. Quant. Spectrosc. Ra., 85, 337-365, 2004.

Oman, L. D., Plummer, D. A., Waugh, D. W., Austin, J., Scinocca, J. F., Douglass, A. R., Salawitch, R. J., Canty, T., Akiyoshi, H., Bekki, S., Braesicke, P., Butchart, N., Chipperfield, M. P., Cugnet, D., Dhomse, S., Eyring, V., Frith, S., Hardiman, S. C., Kinnison, D. E., Lamarque, J. F., Mancini, E., Marchand, M., Michou, M., Morgenstern, O., Nakamura, T., Nielsen, J. E., Olivie, D., Pitari, G., Pyle, J., Rozanov, E., Shepherd, T. G., Shibata, K., Stolarski, R. S., Teyssedre, H., Tian, W., Yamashita, Y., and Ziemke, J. R.: Multi-model assessment of the factors driving stratospheric ozone evolution over the 21st century, J. Geophys. Res., 115, D24306, doi:10.1029/2010JD014362, 2010.

Sauvage, B., Martin, R. V., van Donkelaar, A., and Ziemke, J. R.: Quantification of the factors controlling tropical tropospheric ozone and the South Atlantic maximum, J. Geophys. Res., 112, D11309, doi:1029/2006JD008008, 2007.

Schoeberl, M. R., Douglass, A. R., Hilsenrath, E., Bhartia, P. K., Barnett, J., Beer, R., Waters, J., Gunson, M., Froidevaux, L., Gille, J., Levelt, P. F., and DeCola, P.: Overview of the EOS Aura Mission, IEEE T. Geosci. Remote Sens., 44, 1066-1074, 2006.

Schoeberl, M. R., Ziemke, J. R., Bojkov, B., Livesey, N., Duncan, B., Strahan, S., Froidevaux, L., Kulawik, S., Bhartia, P. K., Chandra, S., Levelt, P. F., Witte, J. C., Thompson, A. M., Cuevas, E., Redondas, A., Tarasick, D. W., Davies, J., Bodeker, G., Hansen, G., Johnson, B. J., Oltmans, S. J., Vomel, H., Allaart, M., Kelder, H., Newchurch, M., Godin-Beekmann, S., Ancellet, G., Claude, H., Andersen, S. B., Kyro, E., Parrondos, M., Yela, M., Zablocki, G., Moore, D., Dier, H., von der Gathen, P., Viatte, P., Stubi, R., Calpini, B., Skrivankova, P., Dorokhov, V., De Backer, H., Schmidlin, F. J., Coetzee, G., Fujiwara, M., Thouret, V., Posny, F., Morris, G., Merrill, J., Leong, C. P., Koenig-Langlo, G., and Joseph, E.: A trajectory-based estimate of the tropospheric ozone column using the residual method, J. Geophys. Res., 112, D24S49, doi:10.1029/2007JD008773, 2007.

Solomon, S., Thompson, D. W. J., Portmann, R. W., Oltmans, S. J., and Thompson, A. M.: On the distribution and variability of ozone in the tropical upper troposphere: Implications for tropical deep convection and chemical-dynamical coupling, Geophys. Res. Lett., 32, L23813, doi:10.1029/2005GL024323, 2005.

Steinbrecht, W., Kohler, U., Claude, H., Weber, M., Burrows, J. P., and van der A, R. J.: Very high ozone columns at northern mid-latitudes in 2010, Geophys. Res. Lett., 38, L06803, doi:10.1029/2010GL046634, 2011.

Stolarski, R. S. and Frith, S. M.: Search for evidence of trend slowdown in the long-term TOMS/SBUV total ozone data record: the importance of instrument drift uncertainty, Atmos. Chem. Phys., 6, 4057-4065, doi:10.5194/acp-6-4057-2006, 2006.
Vömel, H. and Diaz, K.: Ozone sonde cell current measurements and implications for observations of near-zero ozone concentrations in the tropical upper troposphere, Atmos. Meas. Tech., 3, 495-505, doi:10.5194/amt-3-495-2010, 2010.

Waters, J. W., Froidevaux, L., Harwood, R. S., Jarnot, R. F., Pickett, H. M., Read, W. G., Siegel, P. H., Cofield, R. E., Filipiak, M. J., Flower, D. A., Holden, J. R., Lau, G. K., Livesey, N. J., Manney, G. L., Pumphrey, H. C., Santee, M. L., Wu, D. L., Cuddy, D. T., Lay, R. R., Loo, M. S., Perun, V. S., Schwartz, M. J., Stek, P. C., Thurstans, R. P., Boyles, M. A., Chandra, S., Chavez, M. C., Chen, G.-S., Chudasama, B. V., Dodge, R., Fuller, R. A., Girard, M. A., Jiang, J. H., Jiang, Y., Knosp, B. W., LaBelle, R. C., Lam, J. C., Lee, K. A., Miller, D., Oswald, J. E., Patel, N. C., Pukala, D. M., Quintero, O., Scaff, D. M., Snyder, W. V., Tope, M. C., Wagner, P. A., and Walch, M. J.: The Earth Observing System Microwave Limb Sounder (EOS MLS) on the Aura satellite, IEEE T. Geosci. Remote Sens., 44, 1075-1092, doi:10.1109/TGRS.2006.873771, 2006.

Weatherhead, E. C. and Andersen, S. B.: The search for signs of recovery of the ozone layer, Nature, 441, 39-45, doi:10.1038/nature04746, 2006.

WMO (World Meteorological Organization): Scientific assessment of ozone depletion: 2010, Global Ozone Research and Monitoring Project-Report No. 52, Geneva, Switzerland, 2011.

Ziemke, J. R. and Chandra, S.: Seasonal and inter-annual variabilities in tropical tropospheric ozone, J. Geophys. Res., 104, 21425 21442, 1999.

Ziemke, J. R., Chandra, S., and Bhartia, P. K.: Two new methods for deriving tropospheric column ozone from TOMS measurements: The assimilated UARS MLS/HALOE and convective-cloud differential techniques, J. Geophys. Res., 103, 22115-22127, 1998.

Ziemke, J. R., Chandra, S., and Bhartia, P. K.: "Cloud slicing": A new technique to derive upper tropospheric ozone from satellite measurements, J. Geophys. Res., 106, 9853-9867, 2001.

Ziemke, J. R., Chandra, S., and Bhartia, P. K.: A 25-year data record of atmospheric ozone from TOMS Cloud Slicing: Implications for trends in stratospheric and tropospheric ozone, J. Geophys. Res., 110, D15105, doi:10.1029/2004JD005687, 2005.

Ziemke, J. R., Chandra, S., Duncan, B. N., Froidevaux, L., Bhartia, P. K., Levelt, P. F., and Waters, J. W.: Tropospheric ozone determined from Aura OMI and MLS: Evaluation of measurements and comparison with the Global Modeling Initiative's Chemical Transport Model, J. Geophys. Res., 111, D19303, doi:10.1029/2006JD007089, 2006.

Ziemke, J. R., Joiner, J., Chandra, S., Bhartia, P. K., Vasilkov, A., Haffner, D. P., Yang, K., Schoeberl, M. R., Froidevaux, L., and Levelt, P. F.: Ozone mixing ratios inside tropical deep convective clouds from OMI satellite measurements, Atmos. Chem. Phys., 9, 573-583, doi:10.5194/acp-9-573-2009, 2009. 